\title{
The right to water
}

\section{and water rights}

\section{in a changing world}

Colloquium papers, Delft, the Netherlands 



$$
\begin{aligned}
& \text { The right to water } \\
& \text { and } \\
& \text { water rights in a changing world }
\end{aligned}
$$





\section{The right to water and water rights in a changing world}

Papers presented at a colloquium

held on 22 September 2010 in Delft, the Netherlands 


\section{Editing}

Michael R. van der Valk and Penelope Keenan

Design

Michael R. van der Valk | CrossVision

(C) 20 I I by the authors and editors 

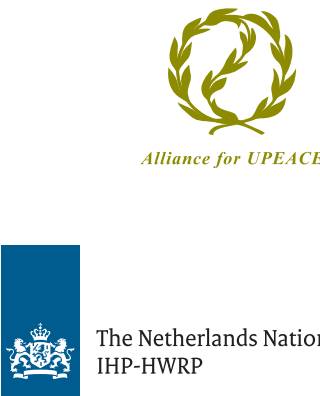

The Netherlands National Committee IHP-HWRP

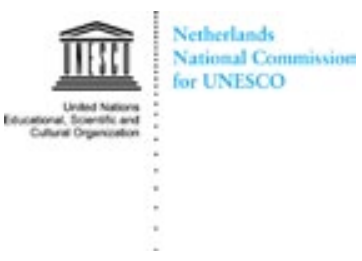

\section{UNESCO-IHE

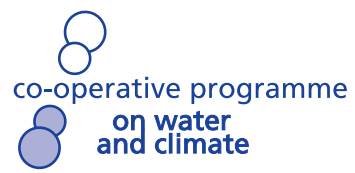


This publication is a contribution of the Netherlands to the International Hydrological Programme (IHP) of UNESCO

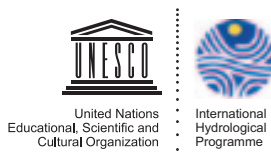

and its activity 'From Potential Conflict to Co-operation Potential PCCP'

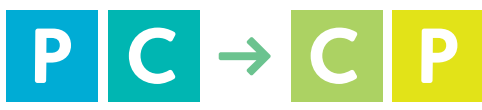




\section{Preface}

\section{The water is always right}

\section{Michael van der Valk}

T $\mathrm{t}$ is now well recognized that population growth and the related 1 global change, including climate change, have a significant impact on the water cycle. In recent years water managers worldwide have taken initiatives to adapt to climate change while at the same time attempting to address other stresses induced by global change.

With the perspective of more frequent and extreme floods, and more sustained droughts in the years to come, water management is adjusting to changes, amongst others by incorporating more uncertainty into decision-making. These changes put extra stress on water management, but even more so in a transboundary context. Where legal agreements have been put in place there is often an assumed stationarity in water availability. Not much is clear, however, about how this works out when the status quo changes, for example when there is less water availability.

As part of a series of UNESCO-related symposia on themes of Water, this publication presents the outcomes of the colloquium 'The right to water and water rights in a changing world', held on 22 September 20 IO at the UnesCo-IHE Institute for Water Education in Delft, the Netherlands. The meeting was organized by the Alliance for UPEACE, the Netherlands National Committee IHPHWRP (for the water programmes of UNESCO and WMO), the Netherlands National Commission for UnEsCo and the UnESCOIHE Institute for Water Education in the framework of the $30^{\text {th }}$

Michael R. van der Valk is Scientific Secretary of the Netherlands National Committee IHP-HWRP, an advisory body for the Government of the Netherlands on the International Hydrological Programme (IHP) of UNESCO and the Hydrology and Water Resources Programme (HWRP) of WMO. 
anniversary of the University for Peace in Costa Rica and the International Day of Peace. The meeting was supported by the Co-operative Programme on Water and Climate (CPWC).

During the colloquium lawyers, ambassadors, hydrologists, social scientists, policy-makers and students discussed the consequences of global change and climatic change on the laws and other legal frameworks related to water management. It became apparent that the impact of climate change on the water cycle needs to be considered and incorporated in future developments of legal documents related to water.

One of the major outcomes of the meeting has been the establishment of a joint initiative on Water and Peace by the UNESCO-IHE Institute for Water Education (based in Delft, the Netherlands) and the UN-mandated University for Peace (UPEACE, based in Costa Rica) in aid of combining the expertise and knowledge of both institutions in water and conflict resolution. As a result of the advocacy work by the Co-operative Programme on Water and Climate (CPWC) a Memorandum of Understanding between the two institutions was signed on I o February 20 I I in Delft.

This publication is a contribution of the Netherlands to the International Hydrological Programme (IHP) of UnEsCo, with special emphasis attributed to its 'From Potential Conflict to Cooperation Potential - PCCP' activities.

Recognizing that water is key to the health of ecosystems and humans alike - and that improved cooperation on water issues will foster peace as well - I sincerely hope the readers will enjoy and use the information and knowledge presented in the publication in their important work related to water, climate change, water law and conflict resolution. After all, "it is in the minds of men that the defences of peace must be constructed".

- Michael R. van Der Valk 


\section{Contents}

Preface - the water is always right

vii

Michael van der Valk

The right to water and water rights in a changing world 22 September 20 I o, UNESCO-IHE Institute for Water Education, Delft, the Netherlands

Marguerite de Chaisemartin

Charlotte Herman

Michael van der Valk

Environmental protection and access to water: the challenges ahead

Laurence Boisson de Chazournes

9

Christina Leb

Mara Tignino

Climate change adaptation in Mozambique

Luís Artur

Dorothea Hilhorst

The current status of the human right to water

Joyeeta Gupta

Sharing water - A necessity for peace in a changing world

Greg Hobbs

Alison Flint

Christie Henke

What role can law play in safeguarding the right to water?

Bas ter Haar 
"I drink your milkshake!"

A short essay about water troubles and the promise of international law coming to the rescue

Juan M. Amaya-Castro

Can international law play a role in safeguarding the security of water supply in a changing world, and if so, how?

Concluding remarks

85

Marius Enthoven 


\title{
The right to water and water rights in a changing world
}

\author{
22 September 2010 , UNESCO-IHE Institute for \\ Water Education, Delft, the Netherlands
}

\author{
Marguerite de Chaisemartin \\ Charlotte Herman \\ Michael van der Valk
}

In the face of global changes, what role can law play in safeguarding basic needs and rights, including that of water? Can law be more effectively mobilized to protect vulnerable communities better against droughts, floods and other climate related disasters? In so doing, to what extent can it contribute to world peace? As laws tend to be rigid, how can they play a more progressive role in a rapidly changing world? Currently water management is stepping away from the idea of stationarity - but what about legal issues? Are they set in stone?

Water is essential to life. However, 884 million people still lack access to good drinking water, and 2.6 billion do not have access to improved sanitation. In the coming decades the world population is expected to expand to 9 billion, with more than 5 billion in Asia in the next 40 years. This will increase competition between users over this scarce resource and may lead to conflicts. As Mr Boutros

Marguerite de Chaisemartin is a consultant with the programme 'From Potential Conflict to Cooperational Potential - PCCP' in the framework of the International Hydrological Programme (IHP) at the Division of Water Sciences at UNESCO, Paris.

Charlotte Herman is Legal Counsel Expert at the Marine Environment Unit, Ministry of Environment, Belgium.

Michael van der Valk is Scientific Secretary of the Netherlands National Committee IHP-HWRP, a governmental advisory body in relation to the International Hydrological Programme (IHP) of UNESCO and the Hydrology and Water Resources Programme (HWRP) of WMO. 
Boutros-Ghali, then Secretary-General of the United Nations, warned in 1985 "the next war in the Middle East will be fought over water, not politics". Climate change and variability have impacts on water resources, and thus on the implementation of the right to water and sanitation. As pointed out by Dr András SzöllosiNagy, Rector of the UNESCO-IHE Institute for Water Education, in order to adapt to climate change and achieve all the Millennium Development Goals (MDGs), the answer is water.

As underlined by the Mayor of Delft, Bas Verkerk, the traditional forms to cope with these kinds of problems are diplomacy, politics, economics and, unfortunately, military means. However, technical and scientific work as well as good dialogue would be much more efficient and could help the world with better solutions than the traditional ones. This is a good reason to enhance the work of professionals and institutions such as UNESCO-IHE, which is serving developing countries as well as students. To this end many other initiatives have started with the aim of turning conflict into peace and water as an agent of change, such as the University for Peace and UNESCO's programme 'From Potential Conflict to Cooperation Potential' (PCCP).

When looking at water from a legal perspective, the year I 997 can be seen as a turning point as the first UN global legal instrument was adopted, namely the Convention on the Law of the NonNavigational Uses of International Watercourses (I 997 Convention), although it is not yet in force. Another important step forward was the adoption of the Resolution A/RES/63/I 24 on the Law of Transboundary Aquifers by the United Nations General Assembly on I I December 2008. On 28 July 20 IO it adopted Resolution A/RES/64/292 in which it recognizes the right to safe and clean drinking water and sanitation as a human right that is essential for the full enjoyment of life and all human rights, and on 30 September 20 I 0 the Human Rights Council adopted a resolution affirming that the human right to safe drinking water and sanitation is derived from the right to an adequate standard of living. It is hoped that we will be able to make things happen so this human right can be translated into action. 
To this end, Ms Laurence Boisson de Chazournes, professor at the Faculty of Law, University of Geneva $(\mathrm{CH})$, stressed that multilateral environmental agreements (MEAs) on environmental protection are important, especially when considered together with the I 997 Convention. Indeed the approaches of these conventions have to be integrated, and in order to provide clean access to water in the future, environmental protection is a necessity. The destruction of wetlands and deforestation for example can be the cause of landslides and other natural disasters, and threaten natural water runoff and groundwater recharge. Although MEAs are not perfect instruments and states do not always enforce or comply with them, they are important instruments of guidance for states and for changing behaviours. Although it is a regional convention, the I 998 Aarhus Convention is a reference instrument with regard to access to information, public participation in decision-making and access to justice on environmental matters. It aims, inter alia, to be used as an instrument to make governments responsible for access to water. Professor Boisson de Chazournes underlined that we have to focus on the relationship between conventions and MEAs, ensuring mutual support in the framework of environmental protection and of human rights, and that we should focus on a global perspective and a multi-level approach concerning water and climate change. Finally she emphasized the necessity of a legal notion of the social, environmental, economic, development pillar, and that environment needs to be the core issue.

\section{Absence of conflicts can mean injustice}

According to Ms Thea Hilhorst, professor in Humanitarian Aid and Reconstruction at Wageningen University (NL), the absence of conflicts can mean injustice; some people do not have the knowledge or the chance to fight for access to water. Using the case of Mozambique as an example, she tried to address how to integrate law at the local level and to involve local people in water management. She noted that one of the reasons that people in Mozambique cannot deal with these floods is the lack of local knowledge which is highly important for water management - due to dis- 
placements caused by conflictive situations. Another challenge is the securitization and politicization of climate change, to find a way to live with floods in the long term and not to view them as a crisis only. Lack of trust of people towards their governments has also to be taken into account. The implementation of climate change adaptation programmes needs to be placed in the context of the local people's livelihoods and involve local communities for the full realization of people's rights and entitlements. Solutions could be the creation of new institutions and new laws, the development of multi-stakeholder initiatives, as well as monitoring these initiatives. Likewise, schemes such as weather insurances should be followed closely in the light of sustainability.

As the UN General Assembly adopted Resolution A/RES/64/292 in July 20 I O, recognizing the human right to water and sanitation, Professor Joyeeta Gupta reminded participants that it is however a very fragile consensus, and urged for a consensus at international level. Ms Gupta is professor of Climate Change Law and Policy at the VU University in Amsterdam and of Water Law and Policy at the UNESCO-IHE Institute for Water Education in Delft (NL). She emphasized the inequality in access to safe drinking water and sanitation, stating that water-carriers are often excluded from education, and the fact that women are often raped on their way to the non-existing toilets. Water is present in the law arena, however access to water and sanitation are not brought up as a key issue. Ms Gupta mentioned three phases of recognition of the human right to water: implicit recognition, such as through the right to life and health, explicit recognition, and independent recognition. In recognizing this right, the General Assembly turned it into a global responsibility, which explains why countries, especially developed countries, remain reluctant in recognizing it. She remarked that $25 \mathrm{UN}$ agencies dealing with water all have their own perspective, and each state reacts in its own way on this issue. With their role becoming more important, private and non-state actors have a different ideology as well, and tend to focus on water as an economic good. Charging for water could be positive in the long term, but not in the short term as not all people are currently in a position to pay for water. Also, private companies are only accountable towards 
their shareholders and not towards the poor. As for adjudication cases, arbitration courts still tend more to recognize the rights of private companies, although they are now starting to refer to the human right to water.

Is the UN General Assembly Resolution on the human right to water and sanitation a good thing?

Responsibility and competition between international institutions are two important considerations when looking at the right to water. The Ambassador of Bolivia, Mr Roberto Calzadilla Sarmiento, whose country took leadership on this issue, expressed his surprise to have seen states abstaining to vote Resolution A/RES/64/292. Professor Gupta said that global responsibility and liability for damages to water supply due to climate change is an explanation for the fear of developed countries to have more responsibility, which led to their abstention to vote in favour of the Resolution. To the opinion of The Netherlands, represented by $\mathrm{Mr}$ Barend ter Haar, Ambassador of the Netherlands to UNESCO, the text of the Resolution raises two main issues: (I) that global responsibility was mentioned in the text while the primary responsibility to ensure the full realization of all human rights belongs to governments and therefore responsibility at both levels should be taken into account; and (2) that the initiative was not helping the efforts of the Independent Expert of the Human Rights Council on this issue.

According to Mr Gregory Hobbs, a Justice of the Colorado Supreme Court (USA), adaptation is essential. Water resources need to be shared in equitable proportions and not be monopolized by the upstream state. In the same way, hallmarks of law can be listed as follows: security, reliability, and flexibility, since being able to evolve is essential as we are confronted with 'wetter wets and drier dries'. Mr Hobbs then focused his intervention on the example of the Colorado River Basin. The Basin's resources are owned by both the government and users through their rights. 
In reminding participants that the thinking of scientists is based on randomness or probability in hydrology, Dr Szöllösi-Nagy asked how law could be reconciled with randomness. Due to climate change the concept of stationarity is no longer acceptable. The United States and Mexico are having problems with setting exact storage obligations. Agreements for the River Nile have remained stationary although the discharge regime has changed.

\section{Law needs to be guided by scientists}

Dr Amaya-Castro, a post-doc researcher at the Faculty of Law at VU University Amsterdam (NL) and an assistant professor at the Department of International Law and Human Rights, United Nations mandated University for Peace (Costa Rica), based his intervention on the 'legalization project of water'. If international law can be considered as weak, legalizing these claims might then be better achieved through domestic law. Stability and reliability are necessary, but flexibility as well, and randomness in law exists through the functions and work of institutions and judges. Proper financing is also required as the involvement of engineers and the guidance they can provide to lawyers and lawmakers. It is in giving or limiting the access to water that law makes water a scarce commodity. If the legalization process exists, it is not sufficient. Declaring the right to access to water and sanitation is a step forward but a too little step forward. The law needs to be guided by engineers and scientists.

The first water war took place in Mesopotamia 3,000 years ago and ended with the first water agreement allowing for sharing of the resource. Law should be considered as a commodity that facilitates cooperation, playing an essential role in preventing water conflicts and respecting people's water rights. Although legislation and conventions are numerous, they are not sufficiently operational and adapted to local livelihoods. The nexus between water and climate change, which concerns access to clean water and sanitation as well as natural disasters has to be more closely looked at. The social impact of programmes and cultural and economic issues all 
have to be considered in order to respect lives, rights and entitlements. Peaceful access to clean water and sanitation needs legislation at all levels. Financing also needs mentioning. Infrastructures cost money, and some would say that water flows towards money, which implies that the poor have less water available. Academia has to join forces and work on practical solutions to answer these key issues. Civil society has an important role as well, especially when institutions and legislation do not ensure them. Water governance is the key to solutions. Lawyers and scientists therefore need to work together and help each other, and help politicians in recognizing and implementing the rights. 


\title{
Environmental protection and access to water: the challenges ahead
}

\author{
Laurence Boisson de Chazournes \\ Christina Leb \\ Mara Tignino
}

\section{Introduction}

An ancient Chinese proverb states that: 'When drinking water, remember its source'. Water is the lifeblood of the human environment; the healthier our environment the cleaner the water that can be drawn directly from it. Hence, environmental protection is of vital importance to guarantee access to clean water in the long term. It therefore seems almost paradoxical to see that the major drivers that threaten ecosystem health and integrity today stem from the ever-increasing water demand by humans. This article analyses the processes by which multilateral environmental conventions (MEAs) assist in the protection of our freshwater resources. These conventions all have in common that water resources management is not their core objective; they rather focus on various other environmental objectives. Yet, these are directly related to sustainable water resources management. The article opens by highlighting the importance of environmental and ecosystem management and protection to ensure safe water supply. This is followed by an analysis of contributions of key MEAs in this regard, before turning to the role that institutions and financial mechanisms play in ensuring compliance with these conventions and in protecting the environment.

Laurence Boisson de Chazournes is Professor of Law, Faculty of Law, University of Geneva. Christina Leb is Research Fellow, Platform for International Water Law, Faculty of Law, University of Geneva. Mara Tignino is Senior Researcher, Platform for International Water Law, Faculty of Law, University of Geneva. 


\section{Environment at the heart of access to water}

Healthy inland water systems have an enormous social, economic, and environmental value. They provide food, drinking water, and transport routes, as well as flood control and water filtration functions. Despite this value, inland water ecosystems, especially of floodplains and wetlands, have for a long time been considered as wasteful use of land. Inland water ecosystems are under continuous threat of being damaged or destroyed by human activities in order to satisfy water needs for irrigation, for hydro-electric power production, as well as for domestic and industrial water supply. Wetlands have to make space for agricultural fields, shipping channels and urban sprawl. It is estimated that $50 \%$ of the global wetland habitat was destroyed in the past century. The estimates for individual countries are even higher; for example for the US, it is estimated that between I 986 and I $99780 \%$ of wetlands were destroyed. ${ }^{\mathrm{I}}$ With the destruction of wetlands, humans destroy natural filter systems for clean water supply. The Central \& Southern Florida Project (C\&SF), which was designed in the I940s, for example converted almost half of the Everglades natural ecosystem for agricultural and urban uses. The hydrologic functions of the remaining wetland areas were also considerably altered. After 50 years in operation, the overall Project resulted in water supply shortages for humans and the natural environment, reduced water storage capacity and an accelerated spread of polluted water and exotic species. The C\&SF Project area is now subject to a Comprehensive Everglades Restoration Plan, which is estimated to take more than 30 years to implement. ${ }^{2}$ The Everglades are probably one of the most drastic examples that highlight how urbanization and agricultural development have put water resources at risk. Hundreds of wetlands around New York City fulfill similar water supply functions as the Everglades. They provide natural filtering for pollution runoff and deliver clean water to millions of New

I W. Darwall, K. Smith, T. Lowe and J.-C. Vié, The Status and Distribution of Freshwater Biodiversity in Eastern Africa, IUCN, 2005 , p. I 3.

2 See 'About CERP: Brief Overview', available at http://www.evergladesplan.org/about/about_cerp_brief.aspx (accessed 6 October 20 I 0 ). 
York City inhabitants. These wetlands also have a natural flood control function. They act like 'sponges' soaking up excessive water from heavy rainfall and snowmelt and then slowly releasing it over time.

The conversion of wetlands for agricultural production and urban sprawl, and deforestation of watersheds take a huge toll on their ecological and hydrologic functioning. The same is true for impacts of misguided land management practices. Change of forest and plant cover has a considerable impact on access to water; it alters local precipitation patterns, groundwater recharge, and it can lead to increase in flooding and landslides. The recent floods in Pakistan have demonstrated that the biggest impact of such humanitarian catastrophes is the subsequent lack of access to safe water resources. In the aftermath of floods, thousands of people contract and often die from diarrhea, cholera or other water-borne diseases because they do not have access to clean drinking water.

Deforestation leads to changes in local precipitation pattern, and can even cause the drying up of whole swaths of land. Forests add to local humidity through evapotranspiration. For example, $50-$ $80 \%$ of moisture in the central and western Amazon Basin remains in the ecosystem water cycle. Rainclouds form transpired moisture and rain back onto the forest. Tree cover also stabilizes groundwater levels, because rainwater is filtered deeper into the soil through the roots. Deforestation causes increase in surface runoff and, at the same time, less moisture remains and is recycled in the local cycle through evapotranspiration. Subsequently there is a decline in local rainfall. Colombia for instance has fallen from the 2 rd to the $24^{\text {th }}$ place in terms of freshwater reserves due to extensive deforestation over the past 30 years. ${ }^{3}$

It is therefore natural that the importance of the environment has also been recognized in international law. Numerous international agreements have been concluded on this issue and international courts have recognized that environmental concerns of states and individuals constitute essential interests that should be pro-

3 'Local and national consequences of loss of local climate regulation', available at http://rainforests.mongabay.com/og02.htm (accessed 8 September 20IO). 
tected. ${ }^{4}$ In a dispute between Hungary and Slovakia concerning the construction of a system of locks and hydropower stations at the Gabčíkovo-Nagymaros site the International Court of Justice made the following statement with respect to activities damaging aquatic ecosystems:

"Throughout the ages, mankind has, for economic and other reasons, constantly interfered with nature. In the past, this was often done without consideration of the effects upon the environment. Owing to new scientific insights and to a growing awareness of the risks for mankind - for present and future generations - of pursuit of such interventions at an unconsidered and unabated pace, new norms and standards have been developed, set forth in a great number of instruments during the last two decades." ${ }^{5}$

Risks to health caused by the contamination of water resources have also been dealt with by the European Court of Human Rights. In the case Tatar v. Romania ${ }^{6}$, the Court of Strasbourg examined the complaints of two individuals relating to damage caused by an industrial accident at a gold mine at Baia Mare near the Tisza River, Romania. The impacts of the accident negatively impacted on the quality of life of the riparian populations and the well-being of the applicants. As a consequence, the Court determined that Romania had failed to respect the right to private and family life of the two claimants. International case law highlights that the protection of aquatic environments is closely connected with human rights concerns, such as access to water.

4 Case concerning the Gabčíkovo-Nagymaros Project, I.C.J. Reports I 997, p 78 .

5 Case concerning the Gabčíkovo-Nagymaros Project, I.C.J. Reports I 997, p 78; See also Legality of the Threat or Use of Nuclear Weapons, Advisory Opinion, I.C.J. Reports I996, and Case Concerning Pulp Mills on the River Uruguay (Argentina v. Uruguay, judgment from 20 April 20 I 0 ).

6 European Court of Human Rights, Tatar v. Romania, 6 July 2009, available at: http://cmiskp.echr.coe.int (accessed 6 October 20 I o). 


\section{The contribution of MEAs to the protection and sustainable management of freshwater resources}

Multilateral environmental agreements may not always work perfectly. Some states, in signing the agreements, may promise more than they are willing or have the capacity to implement. At the same time, these instruments are steps in the right direction, and their potential overall impact on the protection and sustainable use of our natural resources has manifested itself on several occasions. In becoming Parties to an international agreement, states undertake to implement such agreement through the adoption of adequate national measures. This includes the adoption and adaptation of relevant national laws, the establishment of authorities to monitor implementation and any other practical measures they might deem necessary.

\section{Wetlands, biodiversity and access to water}

Two conventions which assist in protecting the contribution of wetlands and aquatic ecosystems to access to water in the long term are the I97 I Convention on Wetlands of International Importance Especially as Waterfowl Habitat (hereinafter referred to as the 'Ramsar Convention') and the I 992 Convention on Biological Diversity.

Convention on Wetlands of International Importance Especially as Waterfowl Habitat

As the title of the Convention illustrates, the original objective of the treaty was to protect the natural habitat of avian fauna, of migrating and non-migrating birds. It has evolved over time towards the protection of wetlands per se. The Convention provides for a list of sites of international importance. The obligation of Contracting Parties to promote the conservation of wetlands is independent of whether a specific site has been included in the list or not (Art.4). For two decades, water per se was treated as a factor 
beyond the scope of the Ramsar Convention. Since I 996, the Conference of Parties (COP) and the Ramsar Convention Secretariat underlined the functions and linkages between water resources and wetlands. A number of guidance notes on water resources management for Parties to the Convention have been adopted since then; they include guidelines for the allocation and management of water for maintaining the ecological functions of wetlands, guidelines for the management of groundwater to maintain wetland ecological character, and a consolidated guidance for integrating wetland conservation and wise use in river basin management. ${ }^{7}$ Given that the number of Contracting Parties is currently at I 60, these guidance documents can have considerable impact on the improvement of the quality of global freshwater resources.

\section{Biodiversity Convention}

The Convention on Biological Diversity (CBD) goes beyond being a treaty that aims at the conservation of biodiversity. It is a processoriented sustainable development convention, which has as its objectives, 'the conservation of biological diversity, the sustainable use of its components, and the fair and equitable sharing of the benefits arising out of the utilization of genetic resources' (Art. I). ${ }^{8}$ Biodiversity is defined in broad terms. It 'means the variability among living organisms from all sources including, inter alia, terrestrial, marine and other aquatic ecosystems and the ecological complexes of which they are part; this includes diversity within species, between species and of ecosystems' (Art.2). This definition includes everything from protozoon to giant redwood trees, and from microbes to elephants. Protecting biological diversity means also protecting its lifeblood, i.e. protecting freshwater resources.

7 Resolution VIII. I, 8th COP, Valencia 2002, Resolution IX. I Annex C ii., Resolution IX. I Annex C, 9th COP, Kampala, 2005, Resolution X. I 9, I oth COP, Changwon, 2008, available at http://www.ramsar.org (accessed 6 October 2010$)$.

8 On this convention see L. Boisson de Chazournes, C. Leb, 'Comment on the Convention on Biological Diversity and its Cartagena Protocol on Biosafety', UN Audiovisual Library of International Law, available at http://untreaty.un.org/cod/avl/intro.html (accessed 6 October 20 I o). 
Freshwater resources are home to an extraordinarily high level of biodiversity providing a vital range of resources essential for sustaining human well-being. For example, although estimates vary, of the 25,000 or so recorded species of fish, about $4 \mathrm{I} \%$ are primarily freshwater species. ${ }^{9}$ Pollution, introduction of invasive alien species, dams, increased water diversion for agriculture and climate change threaten many inland water ecosystems. According to the 20 I 0 IUCN Red List Assessment, 2 I \% of African freshwater plant and animal species are threatened with extinction. ${ }^{\text {1० }}$

The COP to the Convention has identified 'inland waters' as an important thematic area of work. The first element of the work programme, launched in I998, focused on the status and trends of the biological diversity of inland water ecosystems and the identification of options for conservation and sustainable use. ${ }^{\text {I }}$ Noting the alarming rate of loss of inland water ecosystems and species, the COP adopted a revised programme of work in 2004. This revised programme identified the 'restoration of inland water ecosystems' and 'the recovery of threatened species' as priority activities. ${ }^{\mathrm{I} 2}$ The programme provides guidance to States Parties, currently I93, on the adoption of an ecosystem approach for their water management plans and urges them to take the transboundary character of watersheds into account, where relevant.

By focusing on maintenance of water quality for wetlands and biodiversity protection, these two conventions contribute to access to water in wide terms. The pursuit of the conventions' objectives ensures that wetlands and aquatic ecosystems can continue to perform their water purification functions, groundwater recharge and flood control.

9 C. Revenga and Y. Kura (2003) Status and Trends of Biodiversity of Inland Water Ecosystems, Technical Series No. I I, Secretariat of the Convention on Biological Diversity, Montreal, p. 43.

I0 See http://www.iucnredlist.org (accessed 6 October 20 I 0 ).

I Decision IV/4, I 998.

I2 Goal I.3 of the Annex to the Decision VII/4, 'Biological diversity of inland water ecosystems', 7th Meeting of the Conference of the Parties to the Convention on Biological Diversity, Kuala Lumpur, 2004, http://www.cbd.int (accessed 6 October 20 I o). 
The Biodiversity Convention furthermore contributes to the protection of the natural plant cover of ecosystems. As mentioned in the introduction, trees in particular, and plant cover in general, fulfill an important function with respect to the local water balance, the humidity in the air as well as the amount of water in the ground. In this role, the Biodiversity Convention is complemented by the I 994 UN Convention to Combat Drought and Desertification and also by the I 992 Climate Change Convention and its Kyoto Protocol. ${ }^{\mathrm{I} 3}$ Those instruments are among the most ratified international treaties.

\section{Drought and Desertification Convention}

Drought and desertification threaten the livelihoods of over one billion people in I I o countries around the world, costing about US $\$ 42$ billion annually. ${ }^{14}$ Land degradation and desertification in Africa already attracted global attention in the I 970s. However, the Plan of Action which was adopted then was inadequately funded and results were disappointing. Today the I994 Convention to Combat Drought and Desertification has I 94 States Parties. The objective of the Convention is to combat these effects 'through effective action at all levels, supported by international cooperation and partnership agreements' (Art.2.I). These actions include the establishment of national, sub-regional and regional action programmes that are geared towards information and technology exchange, participation of populations and local communities, and financial assistance. Sustainable development and integrated management of water resources play a prominent role in this context, addressing the vital role of land water linkages. The objectives of the Convention are implemented through a

${ }^{13}$ See for more detail L. Boisson de Chazournes, 'Kyoto Protocol to the United Nations Framework Convention on Climate Change', UN Audiovisual Library of International Law, available at http://untreaty.un.org (accessed October 20 IO).

${ }^{14}$ A. Duda, op. cit., p. 2052. 
bottom-up approach. National action programmes are prepared by national consultative committees with participatory community involvement, the support of international cooperation and in cooperation with other Parties (Arts. 9- I 4). The aim is to improve living conditions for the poor residing in drylands and to address the root causes of desertification, such as deforestation and land use change. Improved access to water and its preservation are vital components of dryland rehabilitation and are key objectives of the Convention.

United Nations Framework Convention on Climate Change (UNFCCC)

The long-term objective of the Climate Change Convention is 'to achieve [...] the stabilization of greenhouse gas concentrations in the atmosphere at a level that would prevent dangerous anthropogenic interference with the climate system' (Art.2). One of the measures to mitigate effects of $\mathrm{CO}_{2}$ emissions and equivalents is to protect existing sinks for greenhouse gases and to create new ones. The Kyoto Protocol suggests that absorption of carbon dioxide by trees and soil is a valid means to achieve emission reduction commitments (Art. 3). ${ }^{15}$ Thus it promotes reforestation and plant cover change in favour of flora that absorbs high levels of $\mathrm{CO}_{2}$ emission equivalents. Equally, the UNFCCC Parties recognized the need to 'strengthen and support ongoing efforts to reduce emissions from deforestation and forest degradation' in the Bali Action Plan. In 2008 , the UN launched the UN Collaborative Initiative on Reducing Emissions from Deforestation and Forest Degradation, better known as the UN REDD Programme. It assists developing countries in preparing and implementing national REDD+ strategies. By these measures the UNFCCC and its Protocol also contribute to

I5 Note that there exists strong criticism of this suggestion; e.g. it creates an excuse not to cut emissions in industrial production and other economic activities, it affects forest communities, and can lead to land grabbling and tying up good agricultural land in developing countries to generate emission rights for developed countries. 
the protection of water resources and to the reduction of risks of natural disasters such as landslides and floods.

Climate change is also directly linked to the global water cycle; it passes through the hydrologic cycle. Effects of climate change are most strongly felt through changes in precipitation patterns, and the occurrence and increase in number of extreme hydrologic events. In its Technical Paper 'Climate Change and Water' the Intergovernmental Panel on Climate Change (IPCC) establishes a link between changing water availability and the risks it poses to sustainable development, child mortality rates and poverty reduction. ${ }^{16}$ Given the close link between water and climate, it is interesting to note however that the Convention barely makes any reference to water.

Water is solely referred to with respect to adaptation planning. Article 4 makes brief mention of water resources as one of the areas for which adaptation plans should be developed. Efforts by the international water community to give water a more visible and prominent role in the Climate Change Framework have so far been unsuccessful. The Water and Climate Coalition, which includes members such as CapNet, IUCN, the GWP and Green Cross for example has been lobbying negotiations of the Ad hoc Working Group on Long-term Cooperative Action under the Convention (known as AWG-LCA) to include water as a topic in the long-term action programme. ${ }^{17}$ However, neither the report from the last meeting in Bonn ${ }^{18}$ nor earlier reports from working group meetings include any reference to water. The outcome document of the AWG-LCAA, adopted by the Conference of the Parties held in Cancún in December 2010, makes a footnote reference to water resources management as one of the areas in which Parties should enhance adaptation programmes. Water is not yet recognized as a separate issue warranting attention in long-term adaptation planning.

${ }^{\text {I6 }}$ B. C. Bates, Z. W. Kundzewicz, S. Wu and J. P. Palutikof (eds.), Climate Change and Water, Technical Paper of the Intergovernmental Panel on Climate Change, IPCC Secretariat, Geneva, 2008, p. 47.

${ }^{17}$ See http://www.waterclimatecoalition.org.

${ }^{18}$ Report of the Ad Hoc Working Group on Long-term Cooperative Action under the Convention on its tenth session, held in Bonn from I to I I June 20 I o, UN Doc. FCCC/AWGLCA/20 I / 7 . 


\section{Better governance through public participation}

The last Convention we would like to refer to, with respect to the role of environmental agreements in facilitating sustainable access to water, is the r 998 Convention on Access to Information, Public Participation in Decision-Making and Access to Justice in Environmental Matters, better known as the Aarhus Convention.

Convention on Access to Information, Public Participation in DecisionMaking and Access to Justice in Environmental Matters

In contrast to the other conventions discussed so far, the Aarhus Convention is not of universal scope, but is a regional agreement adopted under the framework of the UN Economic Commission for Europe. The Convention aims at democratizing environmental decision-making in the sense of giving a voice to those who should benefit from environmental protection. It is not only an environmental agreement, but also aims to increase government accountability and transparency. Access to information is part of the human rights obligations with respect to water. ${ }^{19}$ The Aarhus Convention goes further than that. In addition to public information obligations, the Convention grants the public rights with respect to participation in the environmental decision-making process (Arts.6-8). Similar obligations, although less pronounced, have been taken up in the Climate Change Convention (Arts.4 (I) (i) and $6(a))$. Public participation is important in water governance at the local level, because it may furnish critical inputs and enhance the legitimacy, and more importantly, the sustainability of decisions. ${ }^{20}$

The Parties are also called on to promote the principles of the Convention 'in international environmental decision-making proc-

is C. de Albuquerque, Independent Expert on the issue of human rights obligations related to access to safe drinking water and sanitation, Climate Change and the Human Rights to Water and Sanitation, Position Paper, August 20Iо, pp 38f, available at http://www2.ohchr.org (accessed 6 October 20IO).

${ }^{20}$ Ibid, p. 4I. 
esses and within the framework of international organizations in matters relating to the environment' (Art. 3). ${ }^{2 \mathrm{I}}$ The 44 States Parties are hence encouraged to become advocates (or spokespersons) in promoting public participation in environmental decision-making.

\section{The role of institutional mechanisms in facilitating access to water}

Institutional frameworks of MEAs usually include compliance and enforcement mechanisms that can contribute to water resources management. The COPs are the decision-making bodies of MEAs. They promote effectiveness of implementation with their decisions and by means of regular implementation and compliance reviews. To this end, for example, the COP of the Convention on Biodiversity is authorized to examine national reports, parties' obligations, establish subsidiary bodies, and review scientific, technical and technological advice on biological diversity.

The Conferences of Parties fill a void that is due to the absence of a global institutional mechanism addressing water issues. Conferences of Parties of MEAs strengthen international cooperation between states on sustainable water resources management. An example in this respect is given by the 2006 and 2008 decisions of the COP of the Convention on Biodiversity highlighting the need to enhance international cooperation on the management of water resources as well as recognizing that 'cooperative arrangements' contribute to the realization of the goals of the Convention on Biodiversity. The 2006 decision ' $\mathrm{u}$ ]rges Parties and other Governments to ratify and implement the I 997 United Nations Convention on the Law of the Non-Navigational Uses of International Watercourses', while the 2008 decision asks States Parties to 'strengthen relevant international cooperative arrangements for the management of inland watercourses and waterbodies [...] as a contribution towards the achievement of the $20 \mathrm{I} 0$ target of achieving a substantial reduction in the rate of biodiversity

${ }^{21}$ In this sense, the second meeting of the Parties adopted the Almaty Guidelines on Promoting the Application of the Principles of the Aarhus Convention in International Forums, UN Doc. ECE/MP.PP/2005/2/Add.5. 
loss'. Some MEAs include innovative compliance mechanisms, such as the I99 I Espoo Convention on Environmental Impact Assessment in a Transboundary Context and the Aarhus Convention, which is particular in the sense that it provides for public access in the compliance process.

The effectiveness of these mechanisms was illustrated in the dispute on the Bystroe shipping canal. The Bystroe channel project is located in the Danube Delta on Ukrainian territory, and opens an additional navigation channel that links the Danube to the Black Sea. Romania protested this channel invoking violations of both the Aarhus Convention and the Espoo Convention that led to inadequate consideration of the environmental impact of the project. The Meeting of the Parties of the Espoo Convention found that Ukraine had been in non-compliance with its notification obligations and other procedural requirements concerning the environmental impact assessment for the project. The Compliance Committee of the Aarhus Convention equally established that Ukraine had not complied with obligations with respect to public information and participation, in particular affected communities. ${ }^{22}$ In both decisions Ukraine was asked to take steps in order to bring about compliance. Since 2009, the European Commission has been funding a project to support Ukraine in complying with its obligations under the two Conventions and in bringing its national laws in conformity with them.

\section{Harmonization of objectives through coordination and financial activities}

The conventions referred to above promote sustainability of water resources management and availability of safe water supplies from different sectoral angles. Institutional mechanisms, secretariats, and expert groups established under these conventions have started to communicate with each other in order to align and coor-

${ }^{22}$ See Meeting of the Parties Decision IV/2, from 2 I May 2008, UN. Doc. ECE/MP.EIA/ Io; Aarhus Compliance Committee, Report on the Seventh Meeting, Addendum, Findings and Recommendations, UN doc. ECE/MP.PP/C. I/2005/2/Add.3. 
dinate their policies of implementation. For example, in 200 I a Joint Liaison Group was established between the Biodiversity Convention, the Climate Change Convention and the Convention to Combat Drought and Desertification. Through this group the secretariats of the three conventions try to identify possible areas of joint activities or other opportunities in order to enhance coordination through, for example, collaboration among the scientific subsidiary bodies of the conventions ${ }^{23}$, or the development of joint work programmes.

International financial mechanisms also play an important role in integrating these sectoral angles into comprehensive approaches; objectives of the different Conventions are integrated into multi-sectoral programmes for environmental projects and transboundary water resources management. These programmes are put into practice through projects carried out by international financial mechanisms and international implementing agencies, such as the Global Environmental Facility (GEF), UNEP, UNDP, FAO, the World Bank, as well as the African and other regional development Banks. ${ }^{24}$

One can look at the GEF as an example in order to illustrate how integration of objectives works through the system of these mechanisms. The GEF is the dedicated financial mechanism for a series of multilateral agreements; the Biodiversity Convention, the Convention to Combat Drought and Desertification and the Climate Change Convention, as well as the 200 I Stockholm Convention on Persistent Organic Pollutants (or POPs). The latter is another important convention with respect to protecting water quality. POPs are toxic compounds which are not biodegradable and are transported by migratory species, through air and through water. POPs frequently accumulate in aquatic ecosystems and contribute to their degradation. The Convention aims at restricting the

${ }_{23}$ The Subsidiary Body on Scientific, Technical and Technological Advice (SBSTTA) to the CBD, the Committee for Science and Technology (CST) to the UNCDD, and the SBSTA to the UNFCCC.

${ }^{24}$ L. Boisson de Chazournes, The Global Environmental Facility as a Pioneering Institution: Lessons Learned and Looking Ahead, Working Paper No. I 9, Global Environmental Facility, Washington DC, 2003. 
production, the use and the trade, and eventually the production of these compounds.

The GEF funds a large variety of different projects; such as water policy design, scientific studies, watershed restoration projects, projects of habitat protection, and projects to improve the institutional capacity of management institutions. ${ }^{25}$ These projects promote the implementation of multilateral environmental agreements. For example, the GEF co-funded a global assessment study of the World Resources Institute in 2000. This study found that aquatic ecosystems are the most damaged ecosystems overall. The findings of this assessment provided a new driving force to the Biodiversity Convention. As a consequence water was diverted back from irrigation projects into wetlands and an increasing number of sewage discharge treatment plants were installed, in order to repurify aquatic ecosystems. ${ }^{26}$

Institutions such as the GEF and implementing agencies play an important role in integrating the sectoral objectives of the individual environmental conventions. Since water touches literally on all aspects of life, it has to be managed in an integrated way.

\section{Conclusion}

The above analysis illustrates that access to water profits from a large body of international environmental law. These MEAs provide a comprehensive legal framework that seeks to ensure that we do not destroy our environment in the pursuit of our own (economic) needs, as this would disrupt the very basis of our livelihoods. They are crucial complements to other instruments in the fields of international water law, as well as in the area of human rights. The norms and standards contained in MEAs as well as their monitoring mechanisms help in addressing threats to ecosystem health and maintaining sustainability of access to water and satisfaction of basic human water needs. The contents of MEAs percolate down to and are taken up in national laws, state action,

${ }^{25}$ See GEF Project List with respect to the 'international waters' portfolio; available at http://www.gefonline.org.

${ }^{26}$ A. Duda, op.cit., p. 2052. 
and by international organizations and financial mechanisms. Institutional mechanisms established under MEAs furthermore contribute to a constant evolution and enhancement of the legal framework ${ }^{27}$, among which the protection and access to water should be one of the prime objectives.

A major challenge to be dealt with over the course of the next decades pertains to the impact of climate change on water resources. As mentioned, so far it has been difficult to integrate adaptation through water resources management as an explicit programme or factor in the long-term programme of the Climate Change Convention. Given the close linkage between the two, climate and water, one can assume that sooner or later water will play a more visible role. The Guidance on Water and Adaptation to Climate Change, which was developed developed by the UNECE in the framework of the Convention on the Protection and Use of Transboundary Watercourses and International Lakes, is a first and promising step into this direction. This document provides advice to governments and water managers on planning and implementation of cooperative adaptation strategies dealing with the risks of impact caused by climate change on the quality and quantity of water resources.

Considering the overall legal architecture that has been created by multilateral environmental agreements we arrive at a legal understanding of the integrated water resources management (IWRM) approach. One of the benefits of implementing the IWRM approach is to facilitate an integration process between economic development, environmental protection and social welfare. This contributes to the realization of sustainable water resources development promoted by multilateral environmental agreements. Together with their institutional mechanisms, as well as the financial agencies that are concerned with the realization of environmental protection and sustainable development, MEAs provide a comprehensive set of means, which can help to protect and promote access to water.

${ }^{27}$ L. Boisson de Chazournes, 'Environmental Treaties in Time', lecture presented on the occasion of the Elizabeth Haub Prize ceremony in Stockholm, 22 October 2009; reproduced in Environmental Policy and Law, 39/6, 2009, pp 293-298. 


\title{
Climate change adaptation in Mozambique
}

\author{
Luís Artur \\ Dorothea Hilhorst
}

Here we analyse the response to increased flooding, which is partly related to climate change, in Mozambique. We compare governmental responses to local people's strategies and show how climate change adaptation at the national level becomes subject to politics and social negotiation in its implementation. We also show how people's conditions and lifestyles that made them resilient to flooding in the past have been eroded by many factors, that together result in increased numbers of fatalities during floods. It is argued that climate change adaptation, in order to be successful, must be made consonant with historically-grown social and institutional processes, and grounded in the adaptive capacities of local people. This requires a change towards more multi-actor governance of climate changes adaptation, more contextual policies and increased monitoring capacities to review the impact of climate change adaptation measures.

The global policy and scientific climate change communities are increasingly united in bringing the most urgent messages to the world. If the planet is to survive, drastic measures are needed to turn the tide of climate change (NEF and BCAS, 2002; IIED and $\mathrm{NEF}, 2004)$. Despite the urgency of the matter, it is no easy task to align international governments and forge necessary measures on the global level. This chapter focuses on addressing the question of what happens with the message of urgency as it gets further removed from international meeting grounds.

We will use the case of Mozambique to argue that the message of climate change becomes part of everyday realities when it derives local meaning, becomes subject to institutional dynamics and politicking, and leads to outcomes that may have little resem-

Dr Luís Artur and Professor Dorothea Hilhorst, PhD, work at Wageningen University and Research Centre, Wageningen, the Netherlands. 
blance to internationally-agreed measures. Climate change adaptation, in order to be successful, must be made consonant with historically-grown social and institutional processes, and grounded in the adaptive capacities of local people.

We will specifically look at issues of adaptation. There is an emerging consensus that climate change has progressed to such an extent that, along with mitigation, adaptation is necessary. Mitigation deals with the causes of climate change, and mainly targets the production and consumption models of the developed countries. Adaptation deals with the consequences of climate change. As it is clear that climate change hits developing countries hardest, adaptation measures have been directed mainly to poor countries. Adaptation refers to complex processes that are more difficult to capture in 'plans for action' than mitigation. Mitigation depends on national governments and international negotiations, whereas adaptation is primarily a matter of individual households and local managers of natural resources in the context of local and regional economies and societies (Tol, 2005). Adaptation is largely spontaneous and the direction in which systems adapt may not lead to more sustainable development that is coherent with mitigation objectives. Even though governments may attempt to improve the capacity to adapt, the mere existence of capacity is not in itself a guarantee it will be used according to this plan (Burton et al, 2002). Furthermore, the capacity to adapt varies considerably among regions, countries and socio-economic groups and will vary over time (IPCC, 200I). Finally, decisions regarding adaptation to climate change are not isolated from other decisions; they occur in the context of socio-economic and demographic changes as well as transformations in global governance, social conventions and the globalizing flows of capital and labour. This makes it difficult to detach climate change-induced adaptations from actions triggered by other events (Adger et al, 2005).

This paper discusses the responses to climate change by authorities and people in Mozambique. It shows how climate change adaptation becomes subject to politics and social negotiation in the reality of implementation while drawing out policy implications from these findings. It is based on ongoing $\mathrm{PhD}$ research by Luís Artur in the context of the Vulnerability, Adapta- 
tion and Mitigation Programme of the Netherlands Organisation for Scientific Research (NWO), including I 8 months of fieldwork in Mozambique (from January 2007 to July 2008). It is informed by preceding research by Dorothea Hilhorst and Suzette Vonhof in 2004 on community-based climate change programmes of the Mozambican Red Cross. After introducing our conceptual approach to climate change adaptation and natural disasters, we will review issues of disasters and climate change in Mozambique. We will then summarize our findings regarding people's responses and draw conclusions.

\section{Disasters and climate change}

Why focus on natural disasters in a study on climate change adaptation? It has become accepted knowledge that climate change is a factor in the increase of weather extremes. The World Meteorological Organization reported that 2005 broke numerous weather records all over the world, from drought in Brazil, to cold spells in Pakistan and hurricanes in the Atlantic. The economic cost of disasters in 2005 was US\$ I 59 billion (IFRC, 2005). For property insurers it was the costliest year ever. ${ }^{\mathrm{I}}$ The year 2005 also marked the worldwide attention for the increase in disaster risks and the potentials of risk reduction. In January, governments and international institutions came together in Kobe, Japan, at the World Conference on Disaster Reduction. The Plan of Action that was agreed upon, the Hyogo Framework for Disaster Risk Reduction, underlines the importance for addressing underlying risks for disasters. Disasters kill people and livestock, ruin livelihoods, tear communities apart, destroy development efforts and have long-lasting effects on the environment. The Hyogo Framework reflects the growing awareness among civil society organizations, disaster scientists and a growing number of governments like the United Kingdom that the impact of disaster risks, if well understood, can be reduced (DFID, 2006). Disasters are directly undermining the ambitions of the Millennium Development Goals (MDGs). Disaster Risk Reduction (DRR) is not just important to save lives, but also to protect

I Press release Swiss Re 24 February 2005. 
infrastructure, natural resources and development investments. This is not a singular effort. It touches on development planning, humanitarian aid, poverty alleviation, adaptation to climate change, sustainable development, and the realization of the Millennium Development Goals.

The number of floods, droughts, earthquakes, hurricanes and other natural hazards has increased over the past decades. During the I970s, 9 I I disasters were reported, while in the past I o years more than 3,000 have been reported (IFRC, 2005; Guha-Sapir et al, 2003). Statistics on the numbers of affected people by disasters are difficult to interpret due to the lack of international agreement on the definition of 'affected'. The World Disaster Report nonetheless estimates that numbers of affected people have increased since the I970s from 55 to 250 million yearly. Statistics on the socio-economic costs of disaster indicate an inflation-corrected increase in average yearly costs from US\$ I 3 billion in the I 970 S to US\$ 73 billion in the past $\mathrm{I} 0$ years. The economic costs are mainly calculated in industrialized countries. Poor people affected by a disaster have only few properties of value that disappear from view in the statistics. When disasters costs are expressed in terms of percentage of GDP, the 'top ten' lists of affected countries is more or less turned upside down. Despite the increase in frequency and magnitude of disasters, the number of people killed has been reduced from a total of almost one million people in the I 970 s to 5 I 5,000 people in the I 990s. This can be attributed to improved disaster preparedness, including a more effective delivery of emergency aid.

Disasters do not hit indiscriminately. The poor, the elderly, women, children and the handicapped are particularly vulnerable to disasters. Vulnerability to disasters increases, particularly in less developed countries, due to population growth and processes of marginalization. Vulnerability is a crucial concept in understanding the impact of disaster. People are not equally exposed to natural hazards, due to social, economic and political factors (Wisner et al, 2003). Social class, gender, ethnicity, age group, income, health status and citizenship all influence people's vulnerability. Vulnerability to disasters increases, particularly in less developed countries, due to population growth and processes of marginalization. 
On average I 3 times more people died per reported disaster in countries of low human development than in countries of high human development (IFRC, 2004). Poverty and population growth force people to move to steep slopes with the risk of landslides, or to flood- or earthquake-prone areas. Disasters are exacerbated by the HIV/AIDS epidemic: the southern African famine was caused as much by drought as by the erosion of peoples' resilience due to AIDS (De Waal, 2002). Moreover, disasters hit poor people disproportionately; the poor have less means to recover from disasters. For them a disaster is often a push-back into poverty, which makes them more vulnerable to the next disaster.

\section{Climate change and adaptation}

Discussions on climate change adaptation have started to gain momentum since the Rio Conference in 1992 and especially the Kyoto Protocol in I 997. Although it is a relatively young concern, we can already distinguish two generations in the conception of climate change adaptation (Burton et al, 2002). Early definitions were purely climate change-focused. The IPCC (200I) followed the definition of adaptation by Smit et al, (I 999) as "the process of adjustment in ecological-social-economic systems in response to actual or expected climatic stimuli, their effects or impacts". Presently, the IPCC (Adger et al, 2007) uses a reformulated definition, that views adaptation as the process of adjustment or change that reduces vulnerability or enhances resilience in response to observed or expected changes in climate and associated extreme weather events.

The first definition fits into an approach that models climate change scenarios, develops impact models and derives from these data information on which regions, countries (and people) are vulnerable to the modelled impacts. This approach looks at vulnerability as an outcome of climate change and leads to responses that single out direct effects of climate change, for instance in water management, agriculture or disaster risk reduction. The second approach starts by looking at vulnerability as a present inability to cope with external pressures or changes, such as the ones posed by 
climate change. Rather than focusing on climate change scenarios, the second approach focuses on a wider range of contemporary social and economic processes and practices that bring about vulnerability and dampen adaptive capacity. This approach starts from existing policies and regulations to propose policies and measures to improve current adaptations measures (Burton et al, 2002). This chapter follows the second approach. It looks comprehensively at the causes of vulnerability and takes a broad perspective of the policy fields that are relevant to climate change adaptation.

\section{Mozambique: an overview of disasters and climate change}

Mozambique, as one of the poorest country in the world, ranks I 72 out of 182 on the Human Development Index (UNDP, 2009). Natural hazards such as droughts, floods, cyclones and related disasters have all been part of the Mozambican history and can be said to have had an impact on shaping the degree of the country's poverty and vulnerability. Mozambique ranks third on global weather-related damage following Bangladesh and Ethiopia (Buys et al, 2007). In 2000, southern Mozambique was hit by a historical flooding which affected 4.5 million people and claimed about 700 lives. In 200 I another flooding hit central Mozambique and affected another 500,000 people. From 2007 to 2009 , flooding and cyclones recurrently hit central and northern Mozambique. Some regions in the south are cyclically affected by droughts. In a country where most people rely on agriculture, changes in rain patterns may easily turn hazards such as floods and droughts into disasters.

A recent report by the National Institute for Disaster Management (INGC, 2009) shows the effects of climate change in Mozambique. Over the past 50 years, the average temperature has increased by $\mathrm{r} .6^{\circ} \mathrm{C}$, the rainfall season has started later and there has been an increase in the duration of dry spells. Data from EMDAT, which provide the basis of most publications on disasters in Mozambique (GoM, I 988; Christie and Hanlon, 200 I; Negrão, 200 I; INGC, UEM and Fewsnet, 2003; World Bank, 2005) show 
that natural hazards have increased in frequency and intensity over the past decade.

Since I970, Mozambique has been hit by 77 disasters, $4 \mathrm{I}(53 \%)$ of which occurred in the past decade (figure I). There has been an increase of nearly $50 \%$ in the number of people affected by natural hazards when compared with the previous decade. In 2005 , an estimated $94 \%$ of the population was affected by natural hazards (Mafambissa, 2007). The number of people killed has more than tripled compared to the past decade. The increase may partly reflect an improved capacity for data collection, and the substantive increase cannot be attributed to climate change alone. Growing population, environmental degradation and limited alternative sources of livelihood tend to increase people's vulnerability to disasters. There is mounting evidence that poverty reduction programmes have failed to reach the poorest segments of society (James et al, 2005; Hanlon, 2007; UNICEF, 2007).

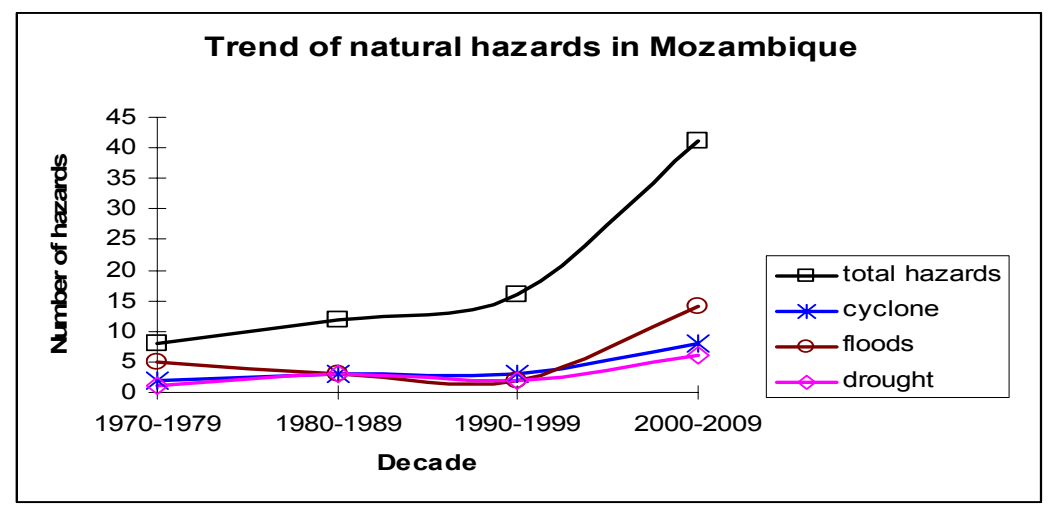

Figure 1: Trends of major natural hazards in Mozambique. Source: Artur (2011), based on EM-DAT.

Droughts have historically been the major hazard affecting nearly 23 million people since I 970. Nonetheless, flooding has become the major natural hazard in the most recent decade. This trend may suggest an improvement on drought and cyclone management, but not much on floods. The cyclone early warning system has improved due to a US\$ 4.7 million donation from USAID. Among others, irrigation schemes have been expanded for drought management and water reservoirs have been established in a num- 
ber of drought prone areas (Marques et al, 2002). NGOs such as the Mozambican Red Cross, World Vision and ActionAid have also introduced new technology in drought prone areas. In comparison, flood management has been more complex, for reasons that will be elaborated below.

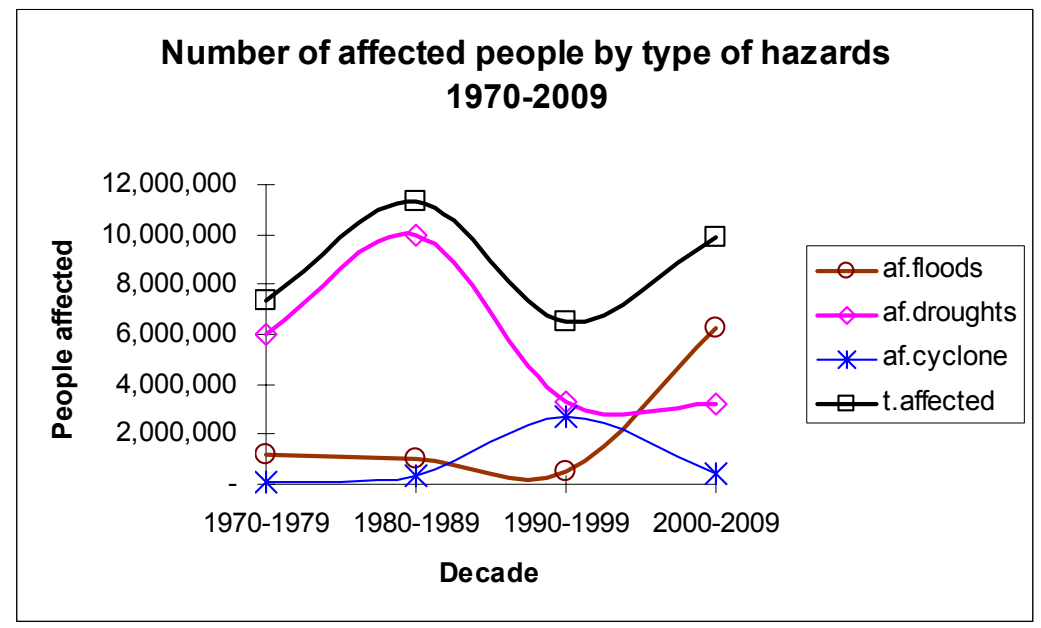

Figure 2: Number of affected people by hazards. Source: Artur (2011), based on EM-DAT.

In response to the extreme weather events in Mozambique, a national master plan on disaster management was approved in 2006. The INGC has shifted its policy framework from disaster response to disaster preparedness. The Ministry of Environment has produced the National Action Plan for Adaptation to Climate Change and the Mozambican Meteorological Institute has established an early-warning system to notify vulnerable, isolated people against erratic and extreme weather events. All these measures and further interventions on disaster risk reduction rely on external donor funding, and the participation of NGOs and actors at local level. 


\section{Government response to climate change: between economic growth and}

environmental concerns

Following the Rio Summit in I992, Mozambique has gradually developed a legal framework to cope with climate change. Under the coordination of the Ministry for Coordination of Environmental Action (MICOA), different working groups and regulatory tools have been established. An inter-institutional working group carried out the first national inventory on greenhouse gases and vulnerability assessment in I 998. This group also led the implementation of the Clean Development Mechanism (CDM) and the National Action Plan for Adaptation (NAPA). Ever since, the country has produced different legal instruments related to climate and sustainable development. These include: (i) Regulation for Environmental Quality Standards and Emissions; (ii) Regulation for Environmental Inspection; (iii) Environmental Strategy for Sustainable Development; (iv) Environmental Law; (v) Environmental Impact Assessment Regulation; (vi) Land Regulation; (vii) Land Legislation; (viii) Water Resources Legislation; (ix) Energy Policy; (x) National Programme for Environmental Management; (xi) Regulation for Mine Activities; and (xii) Territorial Planning Law.

Despite these legal tools, the overall achievement of environmental sustainability (Millennium Development Goal 7) is unlikely to be achieved by 20 I 5 (GoM and UN, 2005). It turns out that, in practice, the Government is specifically focusing on MDG I (half the proportion of people living in extreme poverty) which it hopes to achieve in 2010 . It appears that economic growth competes with environmental concerns.

A major economic policy has been to encourage private foreign investments with different incentives such as limited taxation. Although some of these seem climate-friendly, such as a 45,000 ha license for Jatropha Production for biofuels and investments in hydropower dams, others will certainly increase greenhouse emissions in the years to come. These include the granting of 300,000 ha for coal exploration to the Australian mining company Riversdale. Similarly, the Brazilian company Vale do Rio Doce will extract about 2.4 billion tons of coal over a renewable period of 25 years. Forests in the meantime are being depleted by the exportation of 
wood to China, what some ironically refer to as the 'Chinese takeaway' (Mackenzie, 2006).

Given the extreme poverty, lack of employment and basic infrastructures, it is understandable that the Government is preoccupied with development concerns rather than investments in climate change whose returns may only be visible in the long run. The effect is, however, that climate change adaptation becomes a competing claim in the allocation of budgets and investment decisions by the Government. The optimistic suggestion that climate change adaptation may lead to economic growth and that economic growth can provide the resources for adaptation may be true, but it cannot prevent the reality that decision-making today often entails a negotiation between the two interests.

Actors and stakeholders in climate change in Mozambique: power struggles and strategies

In recent years, internationally-funded programmes for climate change adaptation have been increasing. Major programmes in Mozambique in 2009 were:

i Joint Programme in Environmental Mainstreaming and Adaptation to Climate Change in Mozambique, funded by MDG-F Spain and UNDP;

ii Mozambique Poverty and Environment Initiative, funded by the Government of Ireland;

iii Joint Programme on Strengthening Disaster Risk Reduction and Emergency Preparedness by UNDP;

iv Coping with Drought and Adaptation to Climate Change, funded by GEF;

v World Bank study, foreseen to result in a fund for Climate Change Adaptation.

This has led to competition among Government bodies to handle these large programmes. As aforementioned, the Ministry for Coordination of Environmental Action (MICOA) was initially the coordinating body for climate change adaptation. Development agencies have questioned MICOA's authority by claiming that cli- 
mate change is a development more than an environmental problem. In 2005, the Government of Mozambique created a Ministry for Planning and Development (MPD). In order to mainstream climate change in the national development process, this Ministry has started to claim the coordination of climate change interventions. This has created conflicts between MICOA and MPD over leadership, which became apparent when both Ministries wanted to handle a World Bank project for integrating small-scale farmers into the market, with a large component dedicated to climate change adaptation. Another player is the Ministry for Science and Technology (MCT), which has the mandate to handle interventions regarding science and technology. This Ministry created a working group on climate change in 2007.

The National Institute for Disaster Management (INGC) also has increased its influence on climate change adaptation programmes. It has broadened its mandate by incorporating prevention, vulnerability reduction, reconstruction and development of drought-prone areas. Due to its strong reputation, nearly all international actors have a preference to work with INGC. INGC is handling climate change related projects with UNDP, DFID, GTZ, World Bank, FAO, and the Nordic countries among others. ${ }^{2}$ INGC has also produced the first national study on climate change. At the launch of the study in Maputo in May 2009, the coordination of climate change was a contentious issue, and many guests from competing institutions perceived the initiative as an attempt by INGC to claim the leadership.

Municipalities are also emerging as actors in the climate change arena. When UN-Habitat launched a project aiming to develop mitigation and adaptation mechanisms in two cities of Mozambique, representatives of the municipalities were keen to defend that they had the lawful duty to develop any intervention in their areas of jurisdiction. Development agencies such as the Mozambican Red Cross, Care international, GTZ and World Vision are also unilaterally - or in partnerships -implementing climate change-related projects. And lastly, the private sector is stepping into the climate change arena. The Matola Gas Company

2 Interview with Dr Bonifácio Antonio, Coordination Office Manager, National Institute for Disaster Management (INGC), 28 May 2009. 
(MGC), Cimentos de Moçambique (CM) and Electricidade de Mozambique (EDM) have all asked for authorization to access funds under the CDM. ${ }^{3}$

The emerging problem of this unfolding arena is a lack of coherent strategy and leadership for dealing with climate change. This leads to a dispersion of projects, efforts and funds. It is unclear what the outcomes of the dispersed initiatives will be for adapting to climate change at local level. Actors use this lack of coordination as a leverage to develop and implement climate change interventions according to their own understanding, needs and rules.

\section{People's responses to climate change}

The Zambezi Delta is part of a larger catchment area of the Zambezi River in Africa. The Zambezi River is the fourth largest floodplain river in Africa, the largest watercourse in the sub-Saharan region and the largest system flowing into the Indian Ocean (Davies et al, 2000; Shela, 2000). In Mozambique, the Zambezi Delta covers areas of Mutarara, Mopeia, Caia, Chinde, Marromeu, Inhassunge and Quelimane districts. Based data from the 2007 census (INE, 2007) these delta areas shelter about 965,859 people, mainly from the Sena ethnic group, who build their livelihoods essentially from agricultural production, fishing and petty trading. These activities are indeed highly influenced by flooding regimes which have been part of the history of the Zambezi Delta. Flooding in the Zambezi Delta is a historical phenomenon. Records collected by Chidiamassamba and Liesegang (I 997) date flooding in the Delta as far back as I 586 . In the $20^{\text {th }}$ century alone different authors recorded more than 2 I great floods (Taveira, I 943; Monteiro, I955; Chidiamassamba and Liesegang, I997; Beilfuss, 2005).

The Zambezi Delta has been inhabited for years by people whom, despite seasonal flooding, took advantage of the Zambezi River and its ecosystem to build their livelihoods. Changes pro-

3 Interview with Mr Felício Fernando from the Ministry of Co-ordination of Environmental Affairs (MICOA), Mozambique, 27 May 2009. 
duced over the past 30 years due to an amalgam of factors such as dams, changes in political ideologies, droughts, civil war, displacement, resettlement and population growth tended altogether to push people to live on the floodplains and to rely heavily on natural resources. In doing so, people become physically exposed to flooding and adaptation to flooding becomes a crucial element in crafting the livelihoods. Flooding continues to be the major natural hazard in the Delta and, over the past I o years, the frequency and magnitude of flooding has increased steadily. There were three heavy floods (above $10,000 \mathrm{~m}^{3} / \mathrm{s}$ ) recorded over the decade $2000-$ 2009 , none in the previous decade, and only one of that magnitude in the decade I980-I989. People have developed different strategies over time to adapt to flood risk. This was studied in the Cocorico 'community', who live along the floodplains of the Mopeia district. One of the authors, Luís Artur, lived in Cocorico for about six months and for one year travelled back and forth to Cocorico.

In 2007, Cocorico had about 300 households and nearly I , 500 inhabitants. ${ }^{4}$ Due to its location at the junction of the Zambezi River and its tributary Cuacua, Cocorico is the most floodprone area of the entire Mopeia district and has a long history of flooding. By western standards Cocorico is a poor 'community'. Houses are generally made up of grass and wood and there is a tendency to build them on the heights which remain dry in the wet season and during minor flooding. Most of the households have a house and a granary. There is only one road linking Mopeia Village to Cocorico but it is hardly accessible by car. Livelihoods in Cocorico are based primarily on agriculture and fishing, with a remarkable labour division compelling women to agriculture and domestic spheres while men do fishing and trade. Polygamy and multiple households are common. In most of the cases the wives live distant from each other, and men have a tendency to establish one household on the flood plains where they do their fishing, and one in the higher areas which remains flood-free. All these arrangements are part of historically-grown patterns of household adaptation to flooding.

4 Interview with chief Cocorico, 2 July 2007. 
People in Cocorico have developed adaptation practices to flooding, that range from the construction of their houses, to investment strategies, and to all kinds of social arrangements that can be understood as protecting people against floods. Houses in Cocorico are either located on higher ground or have a thatched roof, and are made of grass and wood. The use of grass and wood is not necessarily a matter of poverty and lack of financial resources, although this may be a relevant factor. In group discussions and individual interviews people suggested that it would be 'irrational' to build conventional houses when there will be a regular flooding, that would wash away the investment. They also suggested that grass and wood houses resist better to flooding events. Some people learned to build brick houses during a period of forced migration to Malawi, and attempted to build one of those in Cocorico. They made bricks, built the houses and used clay to cement the houses and join the bricks. Their houses were the first to disappear during the 200 I flood.

Savings, investments and insurance are not clearly distinguishable in Cocorico. Canoe and fishing nets are, for instance, investments as well as savings. They can also be used as collateral or insurance in cases of credit, marriage and other circumstances. Currency, jewellery and animals are limited due to the occurrence and risk of flooding. A survey which compared the households of the Cocorico floodplains with those of the Mopeia Village, located on higher ground, revealed that households on the floodplains tend to have higher investments in canoes, fishing nets, radios and small-scale poultry (table I). This shows the relevance of practices that combine the livelihood needs of local people with forms of insurance, savings and risk preparedness for flooding. Canoes have multiple purposes, including fishing, trading and means of transportation during extreme floods. Another clear example is the investment in radios, which is also a priority investment in the floodplains. The survey found more households owning radios $(67$ percent) in lower Cocorico than in the upper Mopeia Village (57 percent). Investment in radio has multiple rewards. As environmental clues for flood forecast become less reliable due to environmental changes, people tend to rely on radio for information regarding flooding. In Cocorico, 62 percent of the households were 
informed about the 2007 flooding through radio. Thus, listening to the radio is a preparedness measure for floods. But the radio has more everyday functions: to catch up with emerging or profitable markets for fish or agricultural products, and as a socializing tool in a society where festivities and drinking are customary practice.

Table 1: Investment priorities on the Cocorico floodplain and Mopeia Village.

\begin{tabular}{|c|c|c|c|c|}
\hline \multicolumn{5}{|l|}{ Group Statistics } \\
\hline & Study area & $\mathrm{N}$ & Mean & $\begin{array}{l}\text { Std. } \\
\text { Deviation }\end{array}$ \\
\hline \multirow{2}{*}{ Radios } & Cocorico & 83 & 0.8313 & 0.74603 \\
\hline & Mopeia Village & 114 & 0.6579 & 0.63565 \\
\hline \multirow{2}{*}{ Canoes** } & Cocorico & 83 & 0.6386 & 0.83488 \\
\hline & Mopeia Village & 114 & 0.1316 & 0.41033 \\
\hline \multirow{2}{*}{ Plates** } & Cocorico & 49 & 5.6327 & 1.39484 \\
\hline & Mopeia Village & 105 & 8.9238 & 5.40956 \\
\hline \multirow{2}{*}{ Cups*** } & Cocorico & 49 & 4.2449 & 1.25051 \\
\hline & Mopeia Village & 104 & 5.6923 & 3.64725 \\
\hline \multirow{2}{*}{ Bikes } & Cocorico & 82 & 0.6585 & 0.61302 \\
\hline & Mopeia Village & 110 & 0.6091 & 0.76740 \\
\hline \multirow{2}{*}{ Fishing nets* } & Cocorico & 82 & 0.7439 & 0.95337 \\
\hline & Mopeia Village & 109 & 0.3486 & 0.59901 \\
\hline \multirow{2}{*}{ Spoonsw* } & Cocorico & 50 & 3.5800 & 1.53981 \\
\hline & Mopeia Village & 71 & 5.7887 & 3.35481 \\
\hline \multirow{2}{*}{ Chickens/ducks } & Cocorico & 81 & 5.2099 & 6.61951 \\
\hline & Mopeia Village & 113 & 3.6283 & 4.91389 \\
\hline \multirow{2}{*}{ Goats } & Cocorico & 81 & 0.4815 & 1.81046 \\
\hline & Mopeia Village & 113 & 0.6637 & 1.94390 \\
\hline \multirow{2}{*}{ Pigs } & Cocorico & 81 & 0.6296 & 1.61589 \\
\hline & Mopeia Village & 113 & 0.5575 & 1.44505 \\
\hline \multirow{2}{*}{ Cows } & Cocorico & 81 & 0.0000 & $0.00000 a$ \\
\hline & Mopeia Village & 113 & 0.0000 & $0.00000 a$ \\
\hline \multirow{2}{*}{ Wives* } & Cocorico & 83 & 2.5000 & 1.06904 \\
\hline & Mopeia Village & 114 & 2.0667 & 0.25820 \\
\hline \multirow{2}{*}{ Income per month } & Cocorico & 80 & 1.2200 & 0.50669 \\
\hline & Mopeia Village & 110 & 1.3000 & 0.56747 \\
\hline
\end{tabular}

A $t$ cannot be computed because the standard deviations of both groups are 0 ; * statistical significant differences at $5 \%$, $* *$ statistical significant differences at $1 \%$. Source: Luis Artur (2011) based on fieldwork data. 
Meanwhile, cyclical flooding on the other hand has tended to discourage investments in productive and non-productive items that would be lost during flooding. There is a tendency to avoid accumulating big animals such as goats and cattle or large furniture such as mattresses, beds and tables. Similarly, items for domestic use such as pots, dishes, cups and spoons are possessed mainly according to their utility. In other words, peoples' assets are not merely an expression of lack of capital or accumulation, but provide insight to their adaptation to recurrent flooding.

People also adapt to flooding through social arrangements developed over time. Individual households are dependent on each other through marriage and the sharing of responsibilities, and within households there exists interdependency between females and males, and the elderly and young people. Through group interdependency, individual households can expect help from others during moments of crisis such as extreme flooding. This system was historically guarded by traditional authority, which under contemporary context is being challenged and re-shaped by new developments. This is further reinforced by the group festivities and drinking that are important parts of the community social life.

Adaptation to flooding incorporates a delicate balance of physical, natural, political, socio-cultural, human, symbolic and economic aspects. However, such a balance is currently not possible due to rapid changes and the different actors' interests along the Zambezi Delta. Increasingly the local physical environment is in degradation and the social fabric is less supportive. As a consequence neither the environment nor the social fabric is able to provide enough protection against disaster-related hazards such as flooding.

What is important to realize is that the threats to the lifestyle that people have developed in relation to flooding are manifold. They are environmental, economic, political, social and cultural. The physical environment of the Zambezi Delta has been under continuous change. These factors include upstream dams, reduced precipitation, population increases - and the related needs for crop cultivation plots and firewood as a source of energy. In addition, timber logging is driving deforestation and accelerating the erosion process. An example of a more socio-political element concerns the 
erosion of 'traditional' authorities. Throughout the history of the Delta, traditional authorities fostered the group interdependency system which allowed for some disaster risk reduction. In this regard, ironically, development can also be a factor in undermining resilience to disaster. The manifold development initiatives in the area tend to put local people in contact with external actors and they become perceptive to new opportunities and lifestyles. As a result, they start to challenge their own perception of social order. In group discussions, people suggested that community solidarity is less nowadays as people tend to be more individualistic and concerned with their own affairs. Increasingly, people tend to ask for payments for what used to be, in the past, a benevolence or social activity. The different factors all contribute to explaining the increased trend of people affected and killed by floods over the past I 0 years.

The results of the fieldwork in Cocorico clarifies that addressing adaptation to climate-related hazards is much more complex than measures directly geared to the environmental reduction of disaster risk. It requires looking at the historical and contemporary processes beyond climate and disaster, to analyse how these affect vulnerability to climate-related hazards such as flooding. It is important to study these processes by combining quantitative and qualitative methods. Adaptation is often incorporated in everyday livelihood strategies. Many of the adaptation practices are tacit, and people may be hardly aware of their adaptive properties.

\section{Conclusion}

We can draw five major conclusions from the analyses presented here.

I The emergency discourse prevailing around climate change does not resonate with institutional actors in the climate change adaptation arena in Mozambique. While actors experience the negative impacts of climate change and take the adaptation agenda to some extent seriously, in everyday practice it gets incorporated into the ongoing social processes of classification and differentiation. 
2 The stakes of climate change are high in two ways. Climate change is having visible effects on Mozambique resulting in increased vulnerability to natural disasters. The stakes are also high in the sense that international attention to climate change has opened up an arena where contestation over ideas and resources concerning climate change adaptations takes place at different levels.

3 Technocratic responses to the challenge of climate change adaptation are being politicized in practice, as actors endeavour to appropriate them according to their own interpretations and interests.

4 For local people, climate change is a reality, but they do not perceive it as a separate factor. It becomes one of the elements of change they have to deal with.

5 Many of the local adaptations to climate change consist of tacit livelihood and socio-cultural arrangements; people do not consciously connect to adaptation, yet have a certain functionality in the adaptation process.

For both authorities and people, climate change and climate change adaptation needs to become incorporated in the continuity of everyday practice. The following recommendations have different policy and research implications:

I Investment in empirical research facilities, both quantitative and qualitative, in the processes of climate change adaptation. This kind of research is important to provide reality checks on adaptation policies. Additionally, this is important as research on the social realities of climate change adaptation can reveal emergent properties that have positive or negative effects for adaptation. These can be used as feedback into policy cycles on adaptation.

2 A policy approach to climate change adaptation that is processoriented instead of technocratic and top-down. Actors negotiate adaptation in their everyday practice. The more explicit these negotiations are, the better they can become subject to policy interventions and agreed change toward adaptations. This means investing in multi-stakeholder governance arrangements around climate change adaptation. 
Investment in monitoring and adjustient capacities for climate change adaptation interventions. In view of the analysis presented here, the distinction between planned and spontaneous adaptation practically dissolves, as actors appropriate planned interventions into their 'spontaneous' strategies. Monitoring for unintended outcomes of programmes, both positive and negative, should enable adjustment of policy to changing contexts and outcomes.

\section{References}

Adger, W., S. Agrawala, M. Mirza, C. Conde, K. O’Brien, J. Pulhin, R. Pulwarty, B. Smit and K. Takahashi (2007) Assessment of Adaptation Practices, Options, Constrains and Capacity. In: M. Parry; O. Canziani; in: J. Palutikof, P. van de Linden and C. Hanson (eds) Climate change 2007: Impacts, Adaptation and Vulnerability. Contribution of the Working Group II to the Fourth Assessment Report of the Intergovernmental Panel on Climate Change; Cambridge University Press, Cambridge, pp 7 I $7-743$.

Adger, W, N. Arnell and E. Tompkins (2005) Successful Adaptation to Climate Change Across Scales; in: Global Environmental Change I 5, pp 77-86.

Artur, L.J. (20 I I) Continuities in Crisis. Everyday Practices of Disaster Response and Climate Change Adaptation in Mozambique; PhD Thesis, Wageningen University and Research Centre, Wageningen, $276 \mathrm{pp}$.

Beilfuss, R. (2005) Understanding Extreme Floods in the Lower Zambezi River; Paper presented at the seminar on the water management on the delta of Zambezi held in Maputo 5-6 September 2005 .

Burton, I., S. Huq, B. Lim, O. Pilifosova and E. Schipper (2002) From Impact Assessment to Adaptation Priorities: The Shaping of Adaptation Policy; in: Climate Policy 2, pp I 45- I 59.

Buys, P., U. Deichmann, C. Meisner, T. That and D. Wheeler (2007) Country Stakes in Climate Change Negotiations: Two Dimensions of Vulnerability; The World Bank, Washington DC. 
Chidiamassamba, C. and G. Liesegang (I 997) Dados Históricos sobre ocorrência e tipos de cheias no vale do Zambeze; Paper presented on the workshop on sustainable use of Cahora Bassa dam and Zambezi Valley. Songo 29-09 to 2- I 0- I 997.

Christie, F. and J. Hanlon (200I) Mozambique and the Great Flood of 2000; Long House publications, London.

Davies, B., R. Beilfuss and M. Thoms (2000) Cahora Bassa Retrospective, I 974-I997: effects of flow regulation on the Lower Zambezi River; in: Verh. Internat. Verein. Limnol. vol 27, pp I-9.

DFID (2006) Reducing the Risks of Disasters; 30 March 2006, www.dfid.gov.uk/news/files/disaster-risk-reduction-launch.asp.

GoM and UN (2005) Report on the Millennium Development Goals; Maputo, Mozambique.

GoM (1 988) Rising to the Challenge: Dealing with Emergency in Mozambique: An Inside View; Maputo, Mozambique.

Guha-Sapir, D, D. Hargitt and P.Hoyos (2003) Thirty Years of Natural Disasters I 974-2003: The Numbers. Louvain, CRED/ UCL.

Hanlon, J. (2007) Is poverty Decreasing in Mozambique? IESE, Conference paper \# I 4, Maputo, Mozambique.

IFRC (2004) World Disasters Report of the International Federation of the Red Cross/Red Crescent Societies Geneva, IFRC.

IFRC (2005) World Disasters Report of the International Federation of the Red Cross/Red Crescent Societies Geneva, IFRC.

IIED and NEF (2004) Up in Smoke? Threats From and Responses to the Impacts of Global Warming on Human Development; New Economics Foundation, UK.

INE (2007) III Censo Geral da População e Habitação: Resultados preliminares; Maputo, Moçambique. Available at www.ine.gov.mz, accessed October I I , 2009.

INGC (2009) Synthesis Report. INGC Climate Change Report: Study on the Impacts of Climate Change on Disaster Risk in Mozambique. Van Logchem, B. and Brito, R. (eds); Maputo, Mozambique.

INGC, UEM and Fewsnet (2003) Atlas for Disaster Preparedness and Response in the Limpopo Basin, Maputo, Mozambique.

IPCC ( 200I) Climate Change 200I: Impacts, Adaptations and Vulnerability. Contribution of Working Group II to the Third 
Assessment Report of the Intergovernmental Panel on Climate Change; Cambridge University Press, Cambridge.

James, R, C. Arndt and K. Simler (2005) Has Economic Growth in Mozambique Been Pro-Poor? Maputo, Mozambique.

Mackenzie, C. (2006) Forestry Governance in Zambézia, Mozambique: Chinese Takeaway! Report prepared for FONGZA, Quelimane, Mozambique.

Mafambissa, F. (2007) Efeitos dos Desastres Naturais na Produção Agrícola de Culturas Alimentares e na Segurança Alimentar. IESE, Conference paper \#2 I, Maputo, Mozambique.

Marques, M., M. Vilanculos, J. Mafalacusser and A. Ussivane (2002) Levantamento dos Regadios Existentes no País. Ministério da Agricultura e Desenvolvimento Rural, Moçambique.

Monteiro, G. (I 955) SSE. Sessenta anos de açúcar na Zambézia I 893-I 953 ; Lisboa.

NEF and BCAS (2002) The End of Development? Global Warming, Disasters and the Great Reverse of Human Progress; New Economics Foundation, UK.

Negrão, J. (200 I) O Impacto Socioeconómico das Cheias. Oração de Sapiência por Ocasião da Abertura do Ano Lectivo 200 I2002; Maputo, Moçambique.

Shela, O. (2000) Management of shared river basins: the case of the Zambezi river; in: Water Policy, vol 2, pp 65-8 I.

Smit, B., I. Burton, R. Klein and R. Street (I 999) The Science of Adaptation: A framework For Assessment. Mitigation and adaptation strategies for global change, vol 4, pp I 99-2 I 3 .

Taveira, J. (1943) Açucar de Moçambique- A SSE, Limitada; Imprensa nacional de Moçambique.

Tol, R. (2005) Adaptation and Mitigation: Trade-off in Substance and Methods; in: Environmental Science and Policy, vol 8, pp $572-578$.

UNDP (2009) Overcoming Barriers. Human Mobility and Development. Human Development Report 2009, UNDP, New York.

UNICEF (2007) Childhood Poverty in Mozambique and Budgetary Allocations, New York.

Waal, A. de (2002) New Variant Famine: How Aids has Changed the Hunger Equation; http://allafrica.com/stories/ 2002 I I 20047 I.html. 
Wisner, B, P. Blaikie, T. Cannon and I. Davis (2003) At Risk: Natural Hazards, People's Vulnerabilities and Disaster. London: Routledge.

World Bank (2005) Learning Lessons from Disaster Recovery: The Case of Mozambique. Working Paper \# I 2, Washington DC. 


\title{
The current status of the human right to water
}

\author{
Joyeeta Gupta
}

\section{Introduction}

Although water issues have been on the human agenda since the dawn of civilization, 0.9 billion people still lack access to potable water and 2.6 billion to improved sanitation services. This is not just in the developing world but also in Europe. The potential impacts of climate change on water supply may further exacerbate the existing situation at least for the most vulnerable. This problem is serious in that it affects health and education prospects, and human dignity; together these can have an impact on the productivity of humans.

Several policy efforts have been made at global level to promote the situation of the most vulnerable but these efforts have not yet yielded the expected results. However, since 2008 , the issue is once more on the agenda and a series of activities are now being undertaken to further promote policy development in this field. This has an economic impact in that health agencies can save resources, education agencies can maximize their education, and if social productivity increases then national income can also increase.

Perhaps it may be relevant to firstly stop and consider: Is this problem a global problem? What can be undertaken at global level to deal with the problem of lack of access to water access and sanitation? The answer to the first question is not a straightforward

Joyeeta Gupta is Professor, Climate Change Policy and Law, Institute for Environmental Studies, VU University Amsterdam; Professor, Water and Environmental Law and Policy, UNESCO-IHE Institute for Water Education, Delft. A more detailed version of this paper has been published as J. Gupta, R. Ahlers and L. Ahmed (2010) The Human Right to Water: Moving Towards Consensus in a Fragmented World; in: Review of European Community \& International Environmental Law, vol I 9, issue 3, pp 294-305, November 20 I 0. 
one. In principle, the problem is essentially a local and national one; however, one can argue that the cumulative and common aspects of the problem make it a global problem. Furthermore, to the extent that the problem of climate change and other international measures have an impact on water supplies, the problem takes on a global dimension. In response to the second issue four potential responses can be undertaken at global level: (a) one can make it the responsibility of states to ensure water and sanitation services for nationals; (b) one can make access to water and sanitation services a human right; (c) one can make markets responsible; and (d) one can create solidarity funds and measures to help address these problems. To the extent that there is a link to the climate change problem, there may be need to even think of compensatory funds.

For many policymakers, the issue of water supply and sanitation is a national issue, and hence it is states that should be held responsible for meeting these goals. However, there are many states that simply do not have the resources to implement these goals. Nevertheless, many of these states use their scarce resources for other 'priorities' which may be less critical than water. Making water supply and sanitation services a commodity that can be left to market forces is problematic when one is dealing with people without purchasing power. A critical challenge is whether the private sector will be sensitive to the fact that part of its market may not have purchasing power. Inevitably there will be some resources needed to subsidize states and the poor in meeting their water needs. Some of this can be based on international solidarity and funded from existing aid funds; some can be financed through funds earmarked for climate change adaptation - as it is clear that climate change influences hydrological patterns. But the process is moving slowly. The adoption of the human right to water and sanitation may force even poor states to reshuffle their limited resources towards this sector, impose obligations on the private sector to somehow contribute to dealing with this issue, justify reordering of aid expenditures, and thereby accelerate the process of meeting basic needs worldwide.

This short essay focuses on the development of policy progress at international level in terms of the human right to water. It 
is based on the presentation made at the international conference 'The Right to Water and Water Rights in a Changing World', 2 I September 20I0, in Delft, the participants' comments, and the subsequent scientific paper to be published by Review of European Community and International Environmental Law.

\section{Competing debates}

The problem of access to water and sanitation services is currently being dealt with through the human rights approach. The human rights debate competes with other dominant debates. There are neo-realist debates that focus on making states responsible for their own problems. These debates argue in favour of limiting the scope of global problems and the responsibilities of third party states for domestic challenges in other states. There are neo-liberal debates that focus on making markets more responsible for dealing with the production and distribution of resources. They focus on water as an economic good and the use of pricing as an instrument to deal with water distribution and redistribution. This argument was included in the I 992 Dublin Statement on Water and Sustainable Development. There are legal precedents focusing on the equitable utilization of water and international legal treaties that argue in favour of 'no priority of use' for basic human needs, although they say that 'special regard' should be 'given to the requirements of vital human needs'. Finally, there is the human rights debate which focuses on the rights of humans. Generally speaking this implies responsibilities for national governments; however, since rights are not self-enforcing, individuals with rights may have to use the court system to assert their rights.

Different policy and legal frameworks elaborate on different aspects of these debates. Most national governments have taken on the responsibility to provide water services to their citizens; however, many do not have universal coverage. Most developed countries have met these responsibilities within the domestic context. Within the developed world supranational and regional agreements such as the European Union's Water Framework Directive (WFD) and the United Nations Economic Commission for Europe's 
(UNECE) Protocol on Water and Health have created governance frameworks to deal with basic needs without using the human rights terminology. However, the lack of access to water and sanitation services in many developing countries has provoked a global response. Hence, at the global level the first UN Water Conference in 1977 recognized that 'all peoples [...] have the right to have access to drinking water in quantities and of quality equal to their basic needs'. Subsequently, there has been an International Drinking Water Supply and Sanitation Decade ( I 98 I- I 990) to promote water policies and implementation and in 2000 the Millennium Declaration aimed to prioritize increased coverage of such services. To some extent, this balances the legal position in the UN Convention on the Law on the Non-Navigational Uses of International Watercourses that there is 'no priority of use', i.e. that no use of water has priority over other uses even though vital human needs should be given due consideration.

In the human rights arena, initially the right to water and sanitation was seen as implicitly included in other human rights declarations; subsequently they were explicitly mentioned in specific documents such as the General Comment on the Right to Water which was adopted by the UN Committee on Economic, Social and Cultural Rights. We seem to be now moving into an era where the human right to water and sanitation is being seen as an independent right. The UN Human Rights Council has launched a three-year process to investigate the feasibility of such a right in 2008, and the UN General Assembly adopted a Resolution on the Human Right to Water and Sanitation with I 22 supporting votes in $20 \mathrm{IO}$.

\section{An assessment}

The competition between the different framings of the issue of access to water and sanitation has meant that there is considerable fragmentation in the water governance arena. In other words, there are many different policy and legal instruments operating at global level. Furthermore, although there is a clear trend that shows growing global consensus in different policy documents, legal treaties 
and resolutions regarding the human right to water and sanitation, countries remain that either oppose the concept of a human right to water and sanitation (e.g. the US) or oppose the implicit or explicit elaboration of responsibilities for developed countries to help developing countries in meeting this right (e.g. the Netherlands).

A key question that arises is whether a human rights approach is a relevant, equitable, legitimate and effective approach. One could argue that it is an equitable approach, since it protects the right to survival of humans worldwide by guaranteeing access to basic needs, irrespective of their ability to purchase water and sanitation services in the open market or their technological ability to access water in water scarce areas or access safe sanitation services. It is a legitimate approach since a majority of countries have voted in favour of it, and within countries no one is likely to deny that humans should have access to water. The question is: Is it effective? Why not simply make it the obligation of states to provide the water and sanitation services. The response here is that making states accountable for water and sanitation services is possible where states have access to adequate financial resources, personnel and the physical access to water resources. But many states do not have such access to resources and, besides the changing hydrological regime, may to some extent be attributable to the substantial emissions of greenhouse gases emitted by the developed world. The adoption of this right, especially in the General Assembly version, clearly put the burden of responsibility on all countries to help each other in this area; that there is a responsibility of the global community to ensure that people all over the world have access to water and sanitation services. Many countries argue that they have no obligation to the people of other countries, yet they have almost all accepted the Millennium Development Goals which calls for halving the number of people without access to water and sanitation services. The nature of this obligation is similar - it is based on the idea that people need water, however, it is half-hearted - in that it ignores the needs of the other half and keeps these obligations in the area of charitable actions. By articulating the human right to water, one converts a political goal into measurable and enforceable rights and obligations and this is a 
first step towards guaranteeing human dignity. Although clearly a human right is not self-enforcing, the adoption of such a right empowers the poor and vulnerable, directly or indirectly, through non-state actors who may go to court to enforce these rights on their behalf. As countries are increasingly engaging in liberalizing the water sector and as the notion of water as an economic good takes hold in different societies leading to increased pricing of water, water moves out of the reach of the poorest. The adoption of such a right helps to balance the shift towards an absolute move towards water as an economic good.

Having said that, and acknowledging that the adoption of a human right to water is merely an initial first step, the success of such human rights depends on the follow-up action that is taken by states and non-state actors to make this a legally-binding right, and to collaborate in the implementation of these rights. Although the principle that every human should have access to potable water and sanitation services is clear, it is more difficult to determine how much and what type of services should be made available. The law discusses issues of availability, quality, accessibility (including affordability and non-discrimination) and participation, but translating these principles into measurable indicators has proved to be a challenging task. Furthermore, there have to be court systems and NGOs willing to represent the interests of the poor in implementing these rights. And finally, the nature of the universal obligations remains contested - who has an obligation towards whom, why, when, where and how?

Furthermore, there are implementation challenges. Practical challenges include issues of dealing with physical water scarcity, financing, and the difficulties of often discussing the taboo topic of sanitation. The political challenge lies in the lack of consensus on such a right and the lack of political will to implement such a right. The group-specific challenges are those affecting people in occupied territories, nomads, homeless peoples and indigenous peoples where this challenge comes over and above existing structural problems facing these groups.

But these challenges can be dealt with if social movements and NGOs could continue to be instrumental in ensuring that these issues stay on the political agenda, that the basic needs of 
people are not ignored through a neo-liberal definition of the issues, by creating mass awareness, by using an array of advocacy, lobbying and litigation tools to promote the implementation of this right and by actually helping with the implementation of this right.

\section{Conclusion}

A human rights approach empowers the individual and if the individual or communities who represent the individual can be mobilized, they can then ensure enforcement of their rights. It implies a universal responsibility on all actors and states to try and help with achieving this right. But it does raise questions. How far does the responsibility on other actors go? How does it change the responsibilities of private companies engaged in this sector, if at all? Who is finally to be held accountable for the non-implementation of these rights and how? To what extent are these rights also to be linked to the ongoing discussions on climate change and the potential impact of the climate problem on water access and sanitation? And finally, does this set a poor precedent? Do we then move towards a right of ecosystems to water, a right of animals to water, or a right to irrigation water? 


\title{
Sharing water - A necessity for peace in a changing world
}

\author{
Greg Hobbs, Alison Flint and Christie Henke
}

\begin{abstract}
Alternating flood and drought has always challenged the community governance skills of men and women to conserve and use water for survival and prosperity. The fundamental needs of mankind for food, clothing, tools and shelter are necessarily linked to managing and preserving freshwater.

Patterns of cyclical precipitation suggest that 'a world warming up because of (greenhouse) gases will feature heavier rainstorms in summer, bigger snowstorms in winter, more intense droughts in at least some places and more record-breaking heat waves'.

While governments amble with how to slow global warming, and scientists can't predict exactly when or how much it will snow or rain, water providers must plan for a future full of risk and increasing uncertainty. Effects manifest themselves regionally and locally, watershed by watershed, yet the results of negligence in planning and response have international consequences.
\end{abstract}

If nations fail to agree in the sharing of transboundary surface and groundwater, people and all other creatures suffer. In this era of uncertainty and risk, water sharing is a necessity for peace between neighbors and nations. Water shortage causes conflict, because water is a necessity for all life and commerce. Peace among peoples depends on our ability to adapt to a variable and changing water supply.

Existing legal and institutional arrangements may continue to serve us well, if we find them to be adaptable or can shape them. Certainty is no longer a viable operating principle in water supply

Greg Hobbs is a Justice. Alison Flint and Christie Henke are Law Clerks. The authors work at the Colorado Supreme Court, USA. 
planning, if it ever was, and the risk of doing nothing is unacceptable in light of the consequences.

Adapting existing frameworks and forging new methodologies means we can no longer:

- depend on the recorded history of monitoring gauges, supplemented by tree ring, ice core, and shellfish analyses;

- assume that water rights or licenses to use water we have depended on in the past can be counted on in the future;

- pretend that each nation is sovereign to itself- the hydrology of rivers, together with their connected aquifers, is a public resource that transcends jurisdictional boundaries;

- leave the environment and indigenous communities to fend for themselves;

- allow our water supply infrastructure to fail the clean drinking water needs of a growing world population;

- allow our food supplies to fail because we do not manage water sustainably.

Through learning to adapt, sustain, and survive together by necessity, I wish to therefore propose the following future benchmarks for our collective efforts:

- expect our water managers to conserve well, plan well, and price water for what it's really worth;

- expect our land use decision-makers to shape communities that look and live well and water frugally;

- find our way to restore water ways we've wrecked in the past;

- foster farmers who feed us on less water and homeowners who sprout native grasses and day lilies instead of turf;

- buy, lease, trade and share water through interlinked water systems that serve our greater communities with our pooled financial resources;

- enlarge existing reservoirs, build strategically placed new ones, and employ underground aquifer storage;

- insist on being rate payers of energy utilities that mind a strict water budget and harness the bounty of our strong winds and many sunny days; 
- learn how to develop, in a transparent manner, equitable water sharing criteria for humans and the environment.

In my view, a good water policy includes the following key principles, as outlined in Twenty Basic Principles of a Good Water Policy (Hobbs, 2010).

I Water policy reflects the customs and values of people in communities organized to provide a secure, reliable, and flexible water supply for humans and the environment.

2 Ownership of the surface and groundwater resource always remains in the public.

3 Safe, reliable, and affordable drinking and sanitation water supply is made available to all people.

4 Water necessary for indigenous communities is reserved to them.

5 Water needed to sustain aquatic life, wetlands, riparian zones, and the carrying capacity of watersheds is withdrawn from allocation to other uses.

6 The needs of watersheds of origin within nations, and the needs of nations upstream and downstream of each other, are negotiated, determined and honored.

7 The amount of water available for use is allocated for as many beneficial purposes as possible.

8 Historically exercised water uses currently in existence are identified and confirmed.

9 Natural interaction of tributary aquifers and streams is respected.

I o Surface water and tributary groundwater uses are administered in times of short supply in order of their historical date of actual beneficial use.

I I Water pollution sources are regulated so that water quality is suitable for agricultural, drinking water, recreational, and aquatic life uses.

I 2 Water use efficiency, demand reduction, and conservation measures are employed. 
I 3 Water will be allocated to new uses only if there is an amount available that can be used without injuring pre-existing uses.

I 4 Changes of water uses from existing uses to new uses will be allowed if they do not injure other existing uses.

I 5 A program is instituted for restoring damaged aquatic environment.

I 6 Cooperative forums for adjusting water policy established and just tribunals for resolving water use conflicts are operative.

I 7 Technical assistance grants, loans, and financing mechanisms are made available.

I 8 Stream and aquifer quality and quantity data are collected, maintained, and made public.

I9 Drought and flood plans are prepared and ready for implementation.

20 Public water education is fostered.

\section{Steps towards implementation}

Suggested practical steps for water policy reform were defined in the RULE, a publication by the International Union for Conservation of Nature and Natural Resources (IUCN, 2009).

Step 1: Consider context of water policy reform

- Given countries' different stages of water policy development, it is essential that planners consider proposed reforms in light of historical and political context. In particular, where the political context is sufficiently modern, the ten principles of New Public Management should be incorporated to promote cost reduction in public policy.

Step 2: Assess what type of water policy reform will work best given the existing government structure

- Under authoritative government models, water policy reforms should be introduced and led by the state government. In pluralistic-liberal government, such reforms are best made by negotiation and consortium-building analogous to a marketplace setting. Finally, decentralized, or direct-participatory democracy 
requires all stakeholders' support via networks in order to achieve policy reform.

Step 3: Clearly allocate water rights among users and uses

- Clear allocations of water rights will encourage water users to use it more efficiently.

- Allocation of water among new uses will be allowed if they do not injure existing uses.

Step 4: Introduce proactive, sustainable and just measures that encourage efficiency

- Water policy should pursue human and societal wellbeing, meet ecosystem needs, and protect water quality. Avoiding environmental harm before it occurs is a necessary feature of new water development projects. Thus, conservation measures and principles of sustainability, social justice and equity, and sound economics are central to successful water policy reform.

Step 5: Apply the right technologies

- Adequate technologies appropriate to the geographical and developmental conditions of the country.

Step 6: Apply the principle of recovery of costs for water services

- Water prices should take account of the costs of water services, including environmental and resource costs. At the same time, subsidies must be accounted for in assessing whether the prices paid by water users reflect the full cost of the water service. This is important because water services are often highly subsidized, thereby encouraging damaging overuse of water.

Step 7: Enable sharing and trading of water rights

- Water rights sharing and trading should be made possible via exchanges, stored water banks and leases of water between the municipal and agricultural sector.

Step 8: Ensure support from enabling institutions

- Institutional framework for implementation of the water policy has been designed and is in place. 
- Cooperative forums for adjusting water policy are established and tribunals for resolving water-use conflicts are in operation.

Step 9: Ensure effective governance principles of transparency, certainty, and accountability

- Transparency can be ensured by requiring public decisions, publicly available information and open stakeholder communications.

- Governmental frameworks that clarify and enforce rules should be strengthened to foster public certainty in governmental processes.

- Measures ensuring that water managers and planners are accountable for their acts are fundamental to reliable governance.

Step 10: Guarantee international cooperation

- Water policy reform must transcend borders in countries that share the resource.

The UN Convention on the Law of Non-Navigational Uses of International Watercourses

The United Nations General Assembly approved the UN Convention on the Law of the Non-Navigational Uses of International Watercourses (hereinafter 'the Convention') on May 2 I, I 997, by a vote of $103-3$. Intended as a framework to 'ensure the utilization, development, conservation, management and protection of international watercourses and the promotion of the optimal and sustainable utilization thereof for present and future generations', the Convention seeks to codify customary international water law, as first expressed in the International Law Association's I 966 Helsinki Rules on the Uses of the Waters of International Rivers and further developed by the International Law Commission's nearly 30 years of work on the subject.

The Convention applies broadly to uses of international watercourses, with 'watercourse' defined as 'a system of surface waters and groundwater constituting by virtue of their physical relation- 
ship a unitary whole and normally flowing into a common terminus'. The Convention is explicit that it does not affect existing agreements, but it suggests that parties to such agreements 'consider harmonizing' them with the basic principles of the Convention and encourages States to enter into new agreements applying or adjusting the provisions of the Convention to the characteristics and uses of a particular international watercourse.

The general principles of the Convention include the right of riparian states to the 'equitable and reasonable utilization' of international watercourses, with a corresponding duty to cooperate with other riparians in the protection and development of such watercourses. The Convention also articulates obligations not to cause 'significant harm' to other watercourse states, to cooperate 'on the basis of sovereign equality, territorial integrity, mutual benefit and good faith', and to exchange data and information. The Convention further articulates a mandatory notification and consultation procedure with respect to planned measures which may have a significant adverse effect upon other watercourse states.

The Convention remained open for signature for three years, and enters into force upon ratification by 35 States Parties. As of July 20 I 0, I 6 States are signatories to the Convention, i 9 have ratified it and five are yet to ratify.

In 'The United Nations Watercourses Convention Ten Years Later: Why Has its Entry into Force Proven Difficult?' Salman (2007) argues that countries are reluctant to ratify the Convention due to a variety of often inaccurate perceptions regarding the Convention's provisions and a general dissatisfaction with the compromises it endorsed. States are concerned that the Convention does not fully recognize existing agreements because it suggests States consider harmonizing them with the Convention, and of others that the Convention does not do enough to subject existing agreements to its terms. There is also disagreement over the dispute resolution mechanisms, with some States troubled by the fact that such mechanisms are not binding and others unwilling to commit to compulsory fact-finding. States express further concern about restricting their sovereignty over what ultimately are shared waters. 
Assertions of national sovereignty frequently serve as ideological and logistical barriers to international cooperation over shared watercourses.

In the report, National Sovereignty and International Watercourses, Green Cross International (2000) concludes that the failure of the Convention to enter into force is largely explained by States' unwillingness to give up their 'hard-line stances' with respect to limits on their sovereignty. Green Cross asserts that States need to move away from the perception that the law of international watercourses functions as a restriction on their sovereignty and rather 'towards seeing water as a naturally shared resource'.

Critical of the Convention, Eckstein (2009) believes that the Convention's two primary principles of equitable and reasonable utilization and no significant harm are inadequate in the context of climate change because they 'focus entirely on ensuring the rights of nations rather than on responding to climatic variability...' Eckstein argues that the principles, interpreted as objective criteria, are exceedingly difficult to apply prior to implementation of a particular project and so do not allow states to take a collaborative, forward-thinking, and nimble approach to the consequences of climate change.

Irrespective of these obstacles to ratification and the fact that the Convention has not entered into force, there is a general consensus that the Convention is of significant value as an articulation of the basic principles applicable to international watercourses. According to McCaffrey (200I), 'the success of the Convention does not seem to be dependent upon whether it enters into force. Its influence is more likely to derive from its status as the most authoritative statement of general principles and rules governing the non-navigational uses of international watercourses'. In McCaffrey's view, the Convention clarifies the basic minimum standards universally applicable to international watercourses, thereby reflecting customary international law, and serves both as a starting point for negotiation of new agreements and as an interpretive instrument with respect to existing agreements. 


\section{Groundwater}

The Law of Transboundary Aquifers, prepared by UNESCO's International Hydrological Programme (IHP) and the UN International Law Commission, was endorsed by the UN General Assembly in New York at its 63rd session in December 2008 (United Nations General Assembly, 2008). The nineteen articles endorse the Convention's foundational principles of equitable and reasonable utilization and no significant harm, but they are independent of the Convention and tailored to the unique characteristics of groundwater.

In the context of discussing the Guarani Aquifer of Argentina, Brazil, Paraguay, and Uruguay, Green (20 I o) argues that the draft articles, while endorsing the main principles of the Convention, may be broader in scope because they cover all activities that 'have or are likely to have an impact' on the aquifer. Prior to the draft articles, there was little international law addressing transboundary aquifers, and Green asserts that the Guarani provides an opportunity to apply applicable principles contained in the Convention and endorsed by the draft articles.

In 2003 the four riparians to the Guarani and the World Bank established the Environmental Protection and Sustainable Development of the Guarani Aquifer System Project as a cooperative effort between the four countries to develop a framework for the sustainable management and preservation of the shared groundwater system.

\section{New developments in the climate change context}

A recent report by the National Academy of Sciences' Committee on Stabilization Targets for Atmospheric Greenhouse Gas Concentrations (2010) concludes that "the world is entering a new geologic epoch, sometimes called the Anthropocene, in which human activities will largely control the evolution of Earth's environment". The report attempts to quantify the consequences of different stabilization targets for greenhouse gas concentrations using degrees Celsius of global temperature change as the metric. With respect to 
climate change impacts on streamflows, the report finds that the greatest decreases of streamflow are expected in areas that are currently arid or semi-arid. The report projects a 5- I o percent change in precipitation per degree Celsius of warming, with extreme precipitation events increasing by $3-\mathrm{I}$ o percent per degree.

\section{Tying in water-sharing agreements to the context of climate change}

Existing allocation regimes generally assume the availability of a particular supply of water and that this is highly problematic given climate change-induced variability. In this context of climate change and its attendant uncertainties and risks, there seem to be two primary approaches to governance of shared international waters.

The first is a collaborative, needs-based approach, as expressed by Eckstein (2009) who champions 'collaborative management' on a basin-wide scale, with joint institutional mechanisms and a flexible, adaptive management approach. Eckstein asserts that, where claims based on legal rights tend to exceed available water resources, flexible governance requires a needs-based, rather than rights-based, approach, with allocation determined by cooperative assessment of the minimum requirements of each riparian state. According to Eckstein, such an approach will provide the best adaptation response to climate change uncertainty.

Green Cross International (2000) also supports a cooperative, needs-based approach to allocation, arguing that

[i]t is a terrible mistake that international watercourses have been subjected to [an] "ours" and "theirs" philosophy as it is contrary to their very nature and . . encourages the protectionist and nationalistic attitudes towards water which are the source of most disputes, rather than emphasi[z]ing the fact that the renewable and fluid nature of water is more conducive to sharing than dividing.

Green Cross advocates for 'basin-wide commitment to a shared set of priorities, principles and goals', but fails to articulate how, exactly, water is to be allocated among riparian states. 
The second approach is based on a property-rights model, as championed by Tarlock (20 1 0), who argues that regimes based on cooperative, equitable apportionment will not promote adaptation to climate change in the absence of firm property rights because such regimes promote uncertainty and incentivize States to hoard water. For example, Tarlock believes that the Nile Basin States have little incentive to agree on drought contingency plans, ecosystem protection measures, etc. until each has a recognized entitlement.

However, Tarlock does not simply advocate for strict legal entitlement regimes and recognizes that such regimes provide their own barriers to climate change adaptation by engendering excessive fear of change due to reliance interests, user expectations, and protectionist, use-it-or-lose-it incentives.

\section{Concluding remarks}

Collaborative management and property-rights approaches need not be mutually exclusive. Some legally-protected entitlement is necessary. The notion that States will simply cooperate in the absence of such entitlements is unlikely. Having a legal entitlement also may assuage the fear that, by agreeing to collaborate with respect to management of shared watercourses, states are restricting their sovereignty.

However, entitlements based upon particular quantities of water, such as those established by the Colorado River Compact of I 922 (U.S. Congress, I922), are problematic in the context of climate change, due to the variability of water supplies. Legal entitlements as part of an equitable apportionment regime could be based not on quantity, but on percentage of available supply, as in the Upper Basin Colorado River Compact of I 948. Each riparian state would be entitled to a particular percentage of the entire flow, as measured by an established mechanism at agreed-upon intervals. The actual quantity of water to which a state is entitled during a particular time period would change based upon the available supply. This would incentivize states to conserve water - rather than use the entire quantity to which they are entitled, irrespective of whether that quantity actually is available - to protect their enti- 
tlements by increasing the available supply, thereby benefitting all riparians and the aquatic ecosystem. While still providing the certainty of a property-based, water rights regime, this would provide a more flexible approach compatible with the variability inherent in our warming world. This approach also could provide for protection of aquatic ecosystems through dedication to instream flows of a fixed percentage either of each state's entitlement or of the total available supply (i.e. that percentage would be part of the initial apportionment between states).

This approach also is compatible with the collaborative management ideals espoused by Eckstein (2009) and Green Cross (2000). Indeed, implementation of such an allocation regime would require cooperation, collaborative management, information sharing, and all the other critical components of an effective watersharing regime flexible enough to meet the challenges of climate change. Further, such an apportionment regime could be realized within the universal framework and according to the guiding principles of the Convention.

\section{References}

Eckstein, G. (2009) Water Scarcity, Conflict, and Security in a Climate Change World: Challenges and Opportunities for International Law and Policy; in: Wisconsin International Law Journal, Vol. 27, No. 3 .

Green, B.A. (20 I o) The Guarani Aquifer \& International Groundwater Laws: Advancing Towards a Legal Framework for the Management of a Transboundary Aquifer; in: 13 U. Denv. Water L. Rev., pp. 36I-387

Green Cross International (2000) National Sovereignty and International Watercourses; Geneva, Switzerland, Green Cross International.

Hobbs, G. (20 I o) The Public's Water Resource: Articles on Water Law, History, and Culture; in: Continuing Legal Education In Colorado, Inc., Second Edition, pp. 324-334.

IUCN (2009) RULE, Reforming Water Governance, by A. Iza, A. and R. Stein (eds); IUCN, Gland, Switzerland. 
McCaffrey, M. (200 I) The Contribution of the UN Convention on the Law of the Non-Navigational Uses of International Watercourses; in: Int. J. Global Environmental Issues, Vol. I, Nos. 3/4.

National Academy of Sciences (20 I o) Climate Stabilization Targets: Emissions, Concentrations, and Impacts Over Decades to Millennia; National Academies Press.

Salman M.A. Salman (2007) The United Nations Watercourses Convention Ten Years Later: Why Has its Entry into Force Proven Difficult?; in: Water International, Vol. 32, No. I, pp. II 5 .

Tarlock, A. D. (2000) How Well Can International Water Allocation Regimes Adapt to Global Climate Change?; in: Journal of Land Use and Environmental Law, Vol. I 5, pp. 423-449.

UN General Assembly (2008) Resolution adopted by the General Assembly, The law of transboundary aquifers. I I December 2008, United Nations, A/RES/63/ I 24.

UN General Assembly ( 1997 ) Convention on the Law of the Nonnavigational Uses of International Watercourses; 2 I May I 997, United Nations.

U.S. Congress (1922) Colorado River Compact, 24 November, I 92 2; Santa Fe, New Mexico. 


\title{
What role can law play in safeguarding the right to water?
}

\author{
H.E. Mr Barend ter Haar
}

\begin{abstract}
"Right" as it is used in the phrase "the right to water" is a wonderful word. It implies that we, human beings, do not accept reality as it is, and that we are convinced that reality should be adapted to our view of a just society. "Right" is a wonderful word, yet also a very heavy word; one that should not be used lightly. Taking rights seriously means making laws, respecting laws and, if necessary, enforcing laws.
\end{abstract}

At high school my friends and I enjoyed debating and fooling each other with debating tricks. One of them went more or less as follows: I would write down a sentence on paper and say to my friend: "If you read this sentence out loud you will get \$ I ooo." He knew perfectly well that I did not have \$ I ooo, but he thought "Why not give it a try?", so he said OK and read the sentence aloud. Then, of course, he asked me for the money. But I would say: "I did not say that you would get the money from me, neither did I specify when you will receive it. But I am sure you will receive such an amount of money sometime in the future."

I was reminded of this silly game when I was reading the well phrased international declarations about the right to water and the right to sanitation. Of course safe water and proper sanitation are no laughing matter. But then, how is it possible that while we recognize the right to water, at the same time about 800 million people still lack safe water and two and half billion people lack proper sanitation? Are we serious? Or are we fooling each other?

H.E. Barend ter Haar is ambassador of the Kingdom of the Netherlands to UNESCO. These remarks are made in his personal capacity, so the views expressed are not necessarily those of the government of the Netherlands. 
It is against the background of this question that I will say something about the preconditions that enable laws to play their role. My remarks should be seen as personal observations from an ambassador to UNESCO, who works in the misty world of diplomacy, between visionary statements on the one hand and grim realities on the ground on the other.

\section{What role can law play in safeguarding the right of water and the right of sanitation?}

I will start with two introductory remarks.

One: Safe water and adequate sanitation are of crucial importance to humanity

Whenever an unexpected disaster occurs, such as a hurricane, a war or a new infectious disease, it immediately receives a lot of attention and rightly so. But if an even larger, but continuous disaster kills about I $০, 0 \circ 0$ people every day, such as is the case with the lack of safe water and adequate sanitation, we hardly notice. In subSaharan Africa, for example, half of all hospital beds are occupied by people sick from unclean water or unsafe sanitation. In these countries $90 \%$ of the cause of deaths in children is linked to a lack of safe water and sanitation.

Two: Safe water and sanitation are essential for reaching all Millennium Development Goals

As the director of the Stockholm International Water Institute pointed out: "Without water, we can never fight hunger; without toilets in schools, girls will continue to drop out before finalizing their education; and without adequate sanitation and hygiene, diseases will continue to spread, resulting in increasing child mortality and bad maternal health." 
Let me now mention a number of preconditions for law to play its role.

\section{Water and sanitation are primarily national responsibilities}

First of all we have to decide what type of law we are talking about: national law or international law?

It is tempting to concentrate on the principles of international law with regard to the right to water and the right to sanitation and I will not deny the usefulness of that. I also recognize that some governments would rather discuss international assistance to support their national policies with regard to water and sanitation than discuss these national policies.

However, the key to fulfilling the right to water and the right to sanitation is not to be found in international law, but in national law, because the primary responsibility to assuring the fulfilment of these rights is in the hands of national governments, not in the hands of the international community.

\section{The role of law requires the Rule of Law}

Secondly, the role of law requires the Rule of Law. People that lack safe water and adequate sanitation are usually not rich and powerful, but poor and powerless. Laws can help to assure that they nevertheless get their fair share. But such laws will not work when the rich and powerful are in a position to disregard them. For law to play a role, the Rule of Law is an essential precondition. The Rule of Law means inter alia that laws are obeyed by all - also by the rich and the powerful and also by government officials - and it furthermore requires an independent judicial system. 
Thirdly, it should be noted that corruption undermines the rights of the powerless. Water, as they say, streams uphill to money. To prevent that, we need laws that assure that the poor get their fair share. But some of the rich might be willing to bribe officials in order to get more than their share. If safe water is scarce, the result of such corruption is that the poor will not get a fair share of the water.

It is sometimes argued that in poor countries corruption should be tolerated, as part of the local culture, because, for example, people working at the public water company need the extra income. But think again: if you bribe the water company in order to be able to wash your car, the result might be that a poor family will have to do without sufficient water, possibly leading to disease and death.

People should be empowered to exercise their right to water and sanitation

Furthermore, it is essential that people are empowered to exercise their rights. The best way to fulfil the right to water and the right to sanitation is to give these rights to the people involved. That might sound self-evident, but in practice this is often a real problem because exercising the right to water often requires other rights.

which requires the exercise of other rights

The exercise of the right to water therefore requires the exercise of other rights. When people lack safe water and proper sanitation, they usually also lack other rights, such as property rights of the land they live on and of the buildings they live in. Safeguarding the right to water is therefore closely linked to the safeguarding of other rights. Among the rights that can be essential for exercising the right to water are:

- freedom of expression 
- freedom of assembly

- right to vote

and requires openness about the state of water

And finally: to promote a fair distribution of water it is essential that relevant figures are publicly available, i.e. about storage, use and contamination.

In short:

Law can play an important role in safeguarding the right to water and sanitation provided a number of preconditions are fulfilled, such as Rule of Law; repression of corruption; empowerment of the people concerned; safeguarding the other rights of these people and openness about the state of water. 


\title{
“I drink your milkshake!"
}

\section{A short essay about water troubles and the promise of international law coming to the rescue}

\author{
Juan M. Amaya-Castro'
}

Water, like oil, is a milkshake

In the 2007 film, 'There Will Be Blood', the main character Daniel Plainview, played by Daniel Day-Lewis, sums up a life based on the greedy and successful pursuit of oil in a final scene that is as brilliantly bizarre and shocking as his life has been. The scene depicts an intense confrontation in which Plainview, pretty much out of his mind, reasserts his final and enduring authority over his lifelong rival Eli. Plainview reveals to Eli that Eli's land, which used to have oil, now does not have any, because he has pumped it out of the neighboring parcels, using a procedure called 'draining'. After explaining this, he illustrates it again by describing how he, metaphorically, drank Eli's milkshake by using a straw that reached across the room and into his glass, exclaiming: 'I drink your milkshake! I drink it up!' During the film, we see Plainview's amazing success in reaching into the ground to get out its oil, long before big capitalist enterprises were able to master the technologies and construct an elaborate infrastructure to drain the earth of its liquid hydrocarbons. In this narrative the milkshake becomes the symbol of how there is no liquid that the oil baron cannot, and will not, get to. His will to power is fixated on liquid wealth, and this sweeps away all scruples or sense of shame. From a more distant perspective, Plainview is a character produced by the enormous importance and power that is embodied in oil.

Dr Juan M. Amaya-Castro is Senior Research Fellow, School of Law, Vrije Universiteit, Amsterdam, and Visiting Professor, United Nations mandated University for Peace (UPEACE), Costa Rica.

I I am grateful to Jessica Lawrence for her input and feedback. 
Water is no oil, but it is. It is different in the sense that it seems ubiquitous and it circulates throughout the planet, the atmosphere and our bodies, while oil is ultimately a carbon that also circulates, but over a much longer period of time. We can understand that oil resources will be depleted, but we cannot imagine this for water. But water is like oil in that it needs to be located, processed, and circulated for our use. It is like oil in the sense that it can be wasted and stored. It is like oil in the sense that we can find ourselves, albeit temporarily, without it. It is like oil in the sense that we need it. Most importantly, for the purposes of this essay, it is like oil in the sense that it creates characters like Plainview, who relate water access to wealth and power, who know how to wield this access and are willing to do so. The Plainview character is not just a grotesque personification of the power of oil. He also stands as a symbol of how oil commands individuals as well as corporations, how it organizes economies and the power of states, and how it dictates global geopolitical relations. Water too can be seen to produce individuals, economies, and political organization. It does this through the scarcity of its final product (clean and healthy water), through its asymmetrically scattered provenance, and through the difficulty of its circulation. Water is something that some have (access to), while others don't. It is something that some want to the point of needing it, for their lifestyle, while others need it to the point of wanting nothing else, for their survival. Water, like oil, is a milkshake, and Plainview will drink yours; he will drink it up.

In the past $\mathrm{i} \circ$ to 20 years, amidst growing awareness of how water is an increasingly important cause of conflict and strife, water has found its way to the higher echelons of the global political agenda. With this development, calls for international law have increased. International law is invoked as an instrument to mitigate conflict and to guarantee access. But international law does not arrive at a lawless site; Plainview did not operate, and thrive, in a lawless world. In fact, the power of water (or oil) lies in its ability to operate as a scarce commodity, and commodities need law. Without enforceable property rights it would not be possible to claim ownership over a good, and thus it would be impossible to buy and sell it. 
The (human) right to property is one of the oldest human rights. ${ }^{2}$ In more ways than one, international law and human rights are already present in the field of water politics. The growing call for more international law should thus really be understood as a call for different or new international law, different or new human rights. In this short essay I reflect on what this might entail, on the intrinsic limitations of contemporary water law and politics, and on how this debate plays out in view of the realities of global governance structures.

Water, public and private, and the Role of Law

Broadly speaking, two perspectives on water are always present in debates as in law, and can seem to cancel each other out. On the one hand, water is envisioned as something that is, or at least can be, privately owned. It may be sold, as property, to others, for a price. On the other hand, water is seen as a public good, something to be regulated by the state, which can impose standards for access, pricing, quality control, etc. The push to develop a human right to water is a corollary of this second perspective. Both of these perspectives have been carried as banners by the Left and the Right in the water politics of recent years. They are presented as competing mechanisms for the best allocation and distribution as well as conservation of water. Water has been both nationalized and privatized in the course of the past century and, for the foreseeable future, it will remain caught in the tension between the two poles of these opposing perspectives. In fact, it is impossible to have a system of water management that is completely devoid of some type of market mechanism, such as the setting of prices, if not for the water itself, then for the processes of distribution, storage, cleaning, qual-

2 Not for nothing is John Locke, human rights philosopher, considered to be the philosopher of capitalism. Recently, there is a growing sense that not just the right to property, but that the whole human rights corpus is being molded to become 'trade-related, market-friendly human rights'. See in particular Upendra Baxi, The Future of Human Rights, 2002 (Oxford University Press, New Delhi), and Market Fundamentalisms: Business Ethics at the Altar of Human Rights, Human Rights Law Review (2005) 5 (I): I26. 
ity control, etc. Moreover, from rainfall to aquifers, sources of water are linked to other forms of private property, such as the ownership of land, sewage systems, and hydraulic technology. In the same way, it is impossible to conceive a system of water management that is completely unregulated by the state. After all, property rights to water come in many forms and are constantly challenged by a large variety of users. Rivers change their courses, wells dry up, and a variety of natural forces conspire to reallocate water in ways that necessitate readjustments to the levels of rights. Both the enforcement of these rights and the mechanisms for settling (legal) disputes about them require some form of public authority. If we consider the context of oil and the activities of oil barons such as Plainview, we see that is the product of a mixed bag of public and private arrangements about oil. From land rights through concession rights, and through the whole legal infrastructure that allows an economy to become an oil economy, public arrangements form the cushion in which Plainview can pursue his wealth built on a privately owned capacity to exploit oil. ${ }^{3}$

Law operates by recognizing both the public and private perspectives and by offering a vocabulary for arguing either way, depending on the circumstances. Legal institutions, such as courts, can then decide on which way a particular conflict should be settled. The legal vocabulary itself can be very complex and technical, but even the most straightforward categories, such as 'property' or 'access', can be legally disarticulated and reconfigured in varying ways. This is what is sometimes referred to as law's 'indeterminacy'. For instance, property can be seen as a monolithical claim or as a loose collection of very diverse rights. Property can be asserted while being taxed at the same time, and limitations on what you can do with property abound. ${ }^{4}$ 'Access' too can be perceived very bluntly or in a sophisticated framework of multiple options and

3 Oil too has been the object of much political battles about 'the role of the state' and the multiple ways in which large private actors can be controlled. The recent oil spill involving British Petroleum is an illustration of how thin the surface is under which public-private tensions brew.

4 The state might recognize my right to own the groundwater in my property, while obliging me to sell it a particular price to a registered water company, thus limiting my options in what I can do with it. 
varieties of arrangements. Both can serve neoliberal policies as well as a strongly curtailed state-controlled regime, depending on how they are defined, interpreted and enforced. What matters most is the broader political and cultural context, the reigning views on what works best and on what matters most. These views change over time, and can vary from place to place. They are often the product of historical heritage. For instance, laws regarding drainage - whether it is allowed, whether it can be prevented, and whether there are conditions attached to it - vary considerably, not just among countries, but for example within the various states of the United States. These types of approaches to specific uses of water can sometimes be deeply rooted in the historical and legal culture of a state and can be very difficult to change. Other times they can be easily swayed by changes in people's perceptions about things.

Two expectations are attached to law, and their reconciliation is a never-ending quest. Law has to be predictable, rigid, and knowable. Legal scholars refer to this as 'legal certainty'. There is value attached to knowing what your rights are. It is important too for purposes of public policy and for market mechanisms that there is some predictability and stability with regard to water rights. However, law also has to be responsive. Too much rigidity might cause havoc, and might affect multiple competing rights and interests. A law that is inflexible can also be unfair. Moreover, sometimes the legislative process can become gridlocked, and then it is up to courts to apply common sense in view of changing ideas and unexpected developments. This relationship between legislative and adjudicative processes is, for sure, also embedded in cultural and historical contexts, and varies, sometimes drastically, from place to place and from time to time. In the USA of Plainview's era, the early 2oth century, it would have been hard for native Americans to enforce treaties recognizing their rights to water. Judges then were impervious to their claims and few would think that this was odd. The same would count for labor laws and the rights of unions to strike. These changes are not just apparent in how law is perceived, but also how the legal system constructs its subjects. Oil corporations eventually replaced oil barons; their machismo made 
way for the professionalism of their engineers and lawyers, their ruthlessness became shrouded in a 'green' image. ${ }^{5}$

As we enter the second decade of the 2 Ist century, vague notions, such as 'reasonable use' or 'equitable utilization', dominate international water law. These notions, and others like them, are good examples of legal vehicles that are free to move between the idea of water as a private and as a public good, examples too of how the devil can be in the details. However, national legal systems are replete with similarly mobile notions such as reasonableness, necessity, proportionality and due diligence, among many others. The flexibility of these notions is bound by the cultural and ideological value given to water exploitation, the health of the water industry, the importance of water conservation, and the aesthetics of abundance as well as asceticism. Take, for instance, a city such as Las Vegas. This city can be seen as a feat of human prowess and the human ability to defy the elements. But it can also be seen as a symbol of waste and of the irrationality of the human attitude towards the scarcity of water. Which conception of such phenomena and behaviour occupies the 'common' in common sense will have significant leverage at the moment of deciding what words like 'equitable' and 'reasonable' mean.

As water becomes more important for more people, for people who need it as well as for the Plainviews who can sell it, conflicts over water will multiply, and not just in a quantitative sense. Rather, water will become the site of various types of conflicts. These conflicts will be related to agriculture and industry, as well as to the creation of energy and the supply of drinking water. They will be about sewage and floods, about fisheries and natural heritage sites. They will be about oceans as well as about marshes, about ice as well as about rain. Legal conflicts will deal with the quality of water analyses for the calculation of electricity futures. Water will increasingly be a protagonist in conflicts involving tax

5 Consider the changes in how (bottled) water is perceived and how marketing campaigns play into these changes, making it difficult to distinguish between trend setting and trend following. See e.g., Andrea Larsen, Water Marketing: A New Era for Water Management, March/April 2004, Southwest Hydrology, I 8- I 9. See also Natural Resources Defense Council, Bottled Water: Pure Drink or Pure Hype?, March I 999 (to be found at: http://www.nrdc.org/water/drinking/bw/bwinx.asp, accessed 6/ I 2 / 20 I o). 
law, competition law, and administrative law. In all of these we will see the contestation of ideas and ideological perspectives on what matters and what is best when we talk about water. In each of these multiple areas of (water) law, we will see small versions of the tension between the property right to water and the human right to access to water. We will see contestation about whether water is, ultimately or incidentally, a good that is private or public. And we will see the progression, at times slow and at times abrupt, of changing ideas about what water means in the complex totality of human relations.

International law, the shining armor, and the realities of global (legal) governance

When pursuing the project of legalizing water relations, either by means of strengthening the rules that allow the water industry to optimize the water market and thereby increase redistribution and aggregate water wealth, or by means of allowing more actors to legally challenge the property of those who have (access to) water or water-related resources, it is necessary to consider the systemic implications of entrusting the legal system with the care of complex water management and allocation decisions. For one, a legal system is not just about rules; it is also a legal infrastructure, a complex web of institutions (legislatures and courts, of course, but also supervisory agencies and committees, bar associations and commercial arbitration providers, and a whole variety of companies offering water expertise services to these legal institutions). A legal system is also affected by how it is embedded in the overall political culture in which it operates. Professional sophistication, some form of independence, salaries, and a well-trained force of legal professionals, all this matters as much as traditions of legal institutionalism, political competence, and the capacity to develop and enforce complex policies. It would seem at times that the efforts to legalize water management, conservation and allocation are oblivious to these requirements without which the introduction of legal rules in general - and complex and sophisticated ones in particular - is inconsequential. 
Moreover, one should refrain from too eagerly transplanting a set of rules and institutions from one place to another, without at least wondering about the appropriateness of this. ${ }^{6}$ All types of systemic issues need to be considered according to the context: (a) how centralized should the system be; (b) how much should it rely on litigation; and (c) how much should it depend on supervision, and by whom. It seems really worthwhile to do a cost-benefit analysis, not just of the water issues at stake, but also of the introduction of a particular legal regime, such as a rights-based one, and the functioning and enforcement of this regime. ${ }^{7}$ What would have been the effect, in Plainview's time and place, of the adoption of contemporary legislation about oil exploration and environmental impact assessments? Would it even have made sense?

As it is, the international legal machinery at best provides very broad and general guidelines. However, maybe this is more than enough right now. Maybe the real struggle at the moment should be about the position of water-related political questions on the global agenda, rather than about the introduction of legal rights and obligations. Too much is often expected from the capacity as well as the appropriateness of international (judicial) institutions to fill in the gaps of what was, apparently, not possible at the national level. In fact, one could have serious questions about the sense of devoting so much political energy to the development of an international human right to water. As has been pointed out in the context of the 20 I 0 UNGA Declaration on the Human Right to Water and Sanitiation ${ }^{8}$, this right has already been recognized implicitly and explicitly in numerous legal acts, both nationally and internationally. Nevertheless, the Declaration has also been hailed as a

6 See generally, on the notion and perils of legal transplants, Alan Watson, Legal Transplants: an Approach to Comparative Law, 1993 (2nd ed.), and Ugo Mattei, Efficiency in Legal Transplants: An Essay in Comparative Law and Economics, 14 International Review of Law \& Economics 3 (1994).

7 For instance, how important are 'rules' in a particular political culture? Legal theorists have talked about 'legal fetishism' to refer to situations, and entire political cultures, in which there seemed to be an enormous reliance on overly formalistic articulations of policy. See for a good overview and argument: Julieta Lemaitre, Legal Fetishism at Home and Abroad, 3 Unbound: the Harvard Journal of the Legal Left 2007, 6.

8 UN Doc A/Res/64/292 (July 28, 2010). 
'breakthrough'9. One wonders though: a breakthrough in which direction? Or even, away from what? Sometimes the project of legalization means inaction at the level of policy development, the funding of projects, and the training and empowerment of concrete agents who are currently disenfranchised. It is difficult to assess what is to be gained from the efforts to pass this resolution. But, were there other options; were there other, more concrete goals to pursue? That is a more difficult question to answer.

What is needed is more thorough analysis of who benefits, how, from what exactly, and at whose expense, from a particular step in the direction of legalization. Who is empowered? How does a particular regime affect the (de-)commodification of water? How much does it cost and where does the money flow away from?

What is also needed is a sense of how (international) water governance is not solely affected by international environmental law. Activists and students interested in understanding the legal dimension of international water management would do well to leave international environmental law as a dessert, and look elsewhere for the main course. International environmental law is for sure important, but it tends to see itself in isolation from other fields of law, such as property law, corporate law, and international investment law. But these disciplines and their rules are also important for water management. For instance, how does the international water industry operate? How much does it rely on private international law, on bilateral investment treaties, and on rules pertaining to corporate governance and tax rules? If companies and other organizations dealing and wheeling in water rights look to these areas of law, then why should governments and activists look only to international environmental law and human rights?

9 Office of the High Commissioner for Human Rights, UN Expert Welcomes Recognition as a Human Right of Access to Safe and Clean Drinking Water and Sanitation, (30 July 2010); to be found at: http://www.ohchr.org/en/NewsEvents/Pages/DisplayNews.aspx?NewsID=1024 0\&LangID=E (accessed 6 December 2010). See: McGraw, George S., Defining and Defending the Human Right to Water and its Minimum Core: Legal Construction and the Role of National Jurisprudence (30 November 2010). Available at SSRN: http://ssrn.com/abstract=1721029. 


\section{Conclusion}

For Daniel Plainview, in 'There Will be Blood', it didn't really matter what the rules were. Oil meant power, and he wanted it. Some rules were to his benefit, such as property rules and the rules allowing him to drain oil from adjacent lots of land. Other rules were difficult to enforce, which he knew, and so they were not much of an obstacle. In any case, he knew how to locate himself in the complex field of strong and weak rules, clear and vague norms, and an overly concerned or indifferent government. The legal map would always show some way for him to get to the oil and to make it his own. Eventually though, he would be replaced by the big oil companies and their hordes of lawyers, lobbyists and engineers. Plainview's style would be streamlined and professionalized, to the point that nowadays, when a poor country is found to have big oil reserves, it is often considered a curse, rather than a blessing. Does the growing scarcity of water mean the advent of water barons, à la Plainview, and their successors, the transnational water corporations? Will they drink our milkshake? Or will there be a basic guarantee and a functioning system, either public or private or something in between, which secures access to clean water and sanitation for everyone, in such a way as to avoid large asymmetries, which are the mothers of conflict and strife? 


\title{
Can international law play a role in safeguarding the security of water supply in a changing world, and if so, how?
}

\author{
Concluding remarks
}

Marius Enthoven

Five distinguished professionals in the area of international law and water management presented their view on this theme in light of two major challenges the world faces today with respect to water supply: the impact of climate change and the projected growth of world population to 9 billion in the course of this century.

The need for better access to water is paramount: 900 million people lack access to freshwater resources and 2.6 billion lack basic sanitation. Improvement of the situation is not only required for the well-being and survival of these individuals, but also for the well-being, security and prosperity of humanity as a whole.

Although water has been an issue on the international agenda for decades, improvement has not fully addressed the needs in addition to the rising challenges of climate change by implementing practical solutions.

Among the major hurdles to be overcome, the following were mentioned in particular:

I Access to water is safeguarded by a host of existing laws, treaties and conventions, yet these are not sufficiently operational, integrated and adapted to local needs.

2 Water governance is too fragmented, and a shift to integrated water resource management is needed.

Marius Enthoven is Chairman of the Alliance for UPEACE. 
3 Practical solutions to water access are being hampered by ongoing legal debates about water responsibility and the neoliberal philosophy which considers water as just an economic good, hence subject to unrestricted free market mechanisms and manipulations.

4 Although essentially a local issue, the impacts of water shortage and water access (and their ramifications on total water chains), the size of the problem and the interaction with climate change, make access to water a global governance issue with important strategic dimensions.

5 The human rights approach to water, now firmly advocated by the recent UNGA Resolution on water rights, has a number of advantages over the classical water-legislation approach, but still needs a number of practical improvement follow ups to become effective on the ground.

6 The relationship between water security and climate change needs further elaboration and clarification before synergetic solutions can be employed.

7 For local solutions to water security, more attention should be given to social, cultural and economic aspects, and institutional actors should be educated to changing conditions re. the impacts of climate change.

8 Basic principles of good water policy should be included in all water-related development programmes.

9 A process-oriented rather than technocratic approach involving multi-stakeholder governance is favoured in addressing water problems.

I o Sophisticated water monitoring systems are needed in order to enable national governments to exercise their responsibilities for water security in collaboration with other parties.

The rich harvest of this Colloquium in terms of content, conclusions and recommendations fully underscores the importance of the right to water as a major concern to governments, international law experts, water professionals and other parties involved. This concern can be transformed into an opportunity if the proper strategies are followed and put to work to the benefit of humanity at large. 
The Unesco-Ihe Institute for Water Education and the University for Peace are to be congratulated with their joint effort today to enlarge our insight and knowledge of the right to water as an issue of global importance. I am very pleased that this Colloquium has led to a follow-up initiative for cooperation between UNESCO-IHE and UPEACE on water and peace, which will be developed in the coming months. 


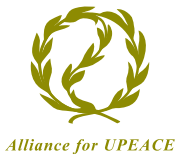

\section{The Alliance for the University for Peace is a non-profit organization, based in Rotterdam, the}

Netherlands. The Alliance was founded in 2002 and serves to support the activities of the university by stimulating cooperation with other institutes in the fields of the diverse peace issues that are covered by UPEACE Master programmes. Through the Alliance UPEACE receives a yearly donation from the Dutch Postcode Lottery. www.upeace.org

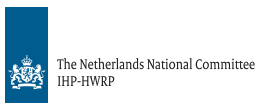

Established in 1965 , the Netherlands National Committee IHP-HWRP

coordinates the Dutch contribution to the International Hydrological Programme (IHP) of UNESCO. The Committee is an interdepartmental advisory commission to the Dutch Ministry of Transport, Public Works and Water Management (V\&W) and the Dutch Ministry of Education, Culture and Science (OCW).

$\checkmark$ www.hydrology.nl

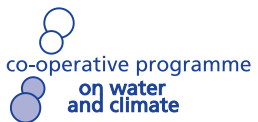

The Co-operative Programme on Water and Climate (CPWC) aims to stimulate

activities in the water sector that contribute to managing the effects of climate variability and change, in particular for the most vulnerable communities.

www.waterandclimate.org

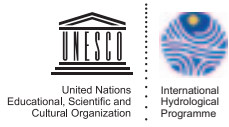

IHP is UNESCO's international scientific cooperative programme in water

research, water resources management, education and capacity-building, contributing to the building of peace, the eradication of poverty and sustainable development.

www.unesco.org

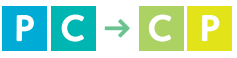

PCCP facilitates multi-level and interdisciplinary dialogues in order to foster peace, cooperation and development related to the management of shared water resources. Through research, education and process support, the programme brings players engaged in transboundary water management together and helps increase the opportunities for actual co-operation and development. PCCP's ultimate objective is to use science diplomacy initiatives to support and maintain peacebuilding processes.

www.unesco.org/water/wwap

\section{UNESCO-IHE TII⿵⺆ The UNESCO-IHE Institute for Water Education carries}

out research, education and capacity building activities in the fields of water, environment and infrastructure. UNESCOIHE continues the work that began in 1957 when IHE first offered a postgraduate diploma course in hydraulic engineering to practising professionals from developing countries.

www.unesco-ihe.org

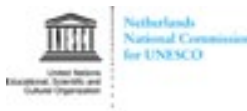

The Netherlands

National Commission for UNESCO

forms the link

between the UNESCO world community and those involved with UNESCO in the Netherlands, such as the national government, professional organisations, and organisations and experts in the fields of education, culture, communication and the sciences. This contact goes in both directions. 
8

co-operative programme

$\bigodot_{\text {ond water }}$

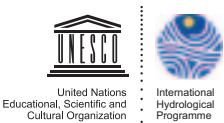

$\mathbf{P}|\mathbf{C} \rightarrow \mathrm{C}| \mathrm{P}$

UNESCO-IHE

IIIII

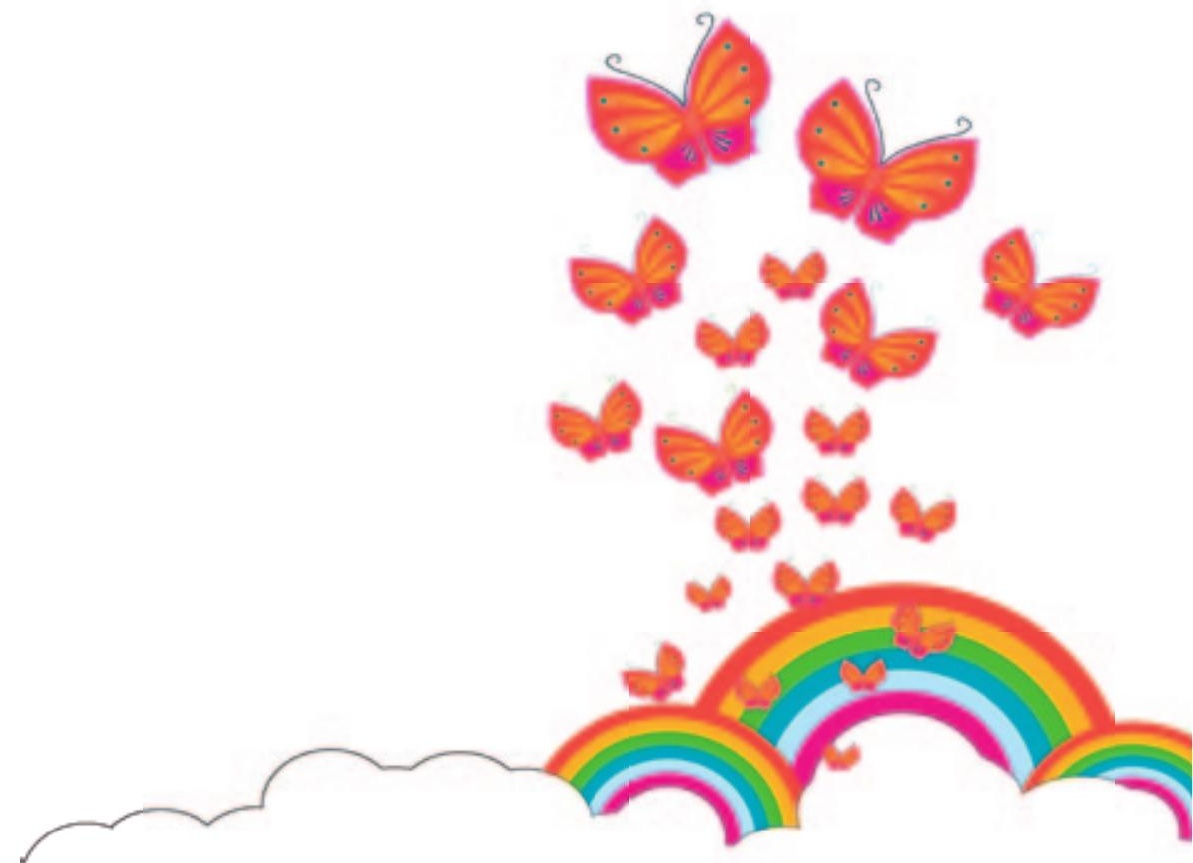

